\title{
Amphi-Atlantic cold-seep Bathymodiolus species complexes across the equatorial belt
}

\author{
K. Olu-Le Roy ${ }^{a}{ }^{*}$, R. von Cosel $^{b}$, S. Hourdez ${ }^{c}$, S.L. Carney ${ }^{d}$ and D. Jollivet ${ }^{c}$ \\ a Département Etude des Ecosystèmes Profonds (DEEP), IFREMER Centre de Brest, BP70-29280 Plouzané, \\ France \\ b Muséum National d'Histoire Naturelle, US MNHN 0602, Taxonomie et Collections, Case Postale 51, 75231 \\ Paris Cedex 0575005 Paris, France \\ ${ }^{\text {c }}$ Station Biologique de Roscoff, UMR CNRS-UPMC 7144, Place Georges Teissier, 29682 Roscoff Cedex, France \\ d Department of Biology, The Pennsylvania State University, University Park, PA 16802-5301, USA
}

*: Corresponding author : K. Olu, email address : Karine.Olu@ifremer.fr

\begin{abstract}
:
Deep-sea bivalves of the subfamily Bathymodiolinae (family Mytilidae) are very widespread and form dense beds in reduced environments such as hydrothermal vents and cold seeps. Bathymodiolus mussels recently discovered on African cold seeps strangely resemble Gulf of Mexico and Barbados seep species. This raises intriguing questions regarding their taxonomic relationships and their dispersal capabilities across the Atlantic equatorial belt. The morphological study of the shell and soft parts of mussels from either sites of the Atlantic shows that they form two distinct groups: the Bathymodiolus boomerang group (also including Bathymodiolus heckerae and a species from Africa), and the Bathymodiolus childressi group (also including Bathymodiolus mauritanicus and one species from Barbados). Phylogenetic relationships inferred from the nucleotide sequences of the ribosomal DNA internal transcribed spacer (ITS-2) and mitochondrial cytochrome c oxidase subunit I (COI) confirmed morphological analyses and the existence of two amphi-Atlantic complexes of species. Both ITS2 and COI phylogenies indicate almost no difference between the two eastern Atlantic seep mussels (Bathymodiolus sp. A and B. mauritanicus) and their western Atlantic counterparts (B. boomerang and Bathymodiolus sp. B; Barbados Prism cold seeps). In the B. boomerang complex, B. heckerae seems to differ from the Barbados and the African species, whereas these latter two are not distinguishable. In the $B$. childressi complex, relationships are less clear and do not support the description of new species from the Barbados. Past and present-day connections across the Atlantic are discussed in the light of both larval dispersal capabilities of the mussels and the equatorial Atlantic circulation to appreciate whether these species could represent true amphi-Atlantic species.
\end{abstract}

Keywords: Bathymodiolus; Cold seeps; Amphi-Atlantic species; Mitochondrial cytochrome oxydase; rDNA ITS2

\section{Introduction}

Within the family Mytilidae, all vent and seep mussels belong to the subfamily Bathymodiolinae, genus Bathymodiolus Kenk and Wilson 1985; Gigantidas Cosel and Marshall 2003; and Tamu Gustafson et al. 
1998, or to the subfamily Modiolinae, genera Idas Jeffrey 1876. The mussels dominate numerous hydrothermal-vent and cold-seep communities worldwide with a total of 35 species or morphospecific entities of Bathymodiolinae mussels (R. von Cosel, unpublished list). In the Atlantic, nine mytilid species so far have been described from deep chemosynthetic environments, including seven from cold seeps. In addition, two records from seeps remain to be identified, one on the Barbados accretionary prism and one from the Gulf of Guinea. Five mussels belonging to the genera Bathymodiolus, Tamu and Idas are known from cold seeps of the Gulf of Mexico (Gustafson et al., 1998), including one species, Bathymodiolus heckerae Gustafson, Turner, Lutz and Vrijenhoek 1998, found at the West Florida Escarpment (Hecker, 1985, Won et al., 2002) and later reported from the Blake Ridge seep sites off North Carolina (Van Dover et al., 2003). Two species, Bathymodiolus boomerang Cosel and Olu 1998 and the undescribed Bathymodiolus sp. B, co-occur at the Barbados prism (Jollivet et al., 1990; Olu et al., 1996). Two vent species, Bathymodiolus azoricus Cosel and Comtet 1999 and Bathymodiolus puteoserpentis Cosel, Métivier and Hashimoto 1994, have been described from the Mid-Atlantic Ridge (Desbruyères et al., 2000) where they locally hybridize (O'Mullan et al., 2001). Until recently, very few records were available from the European and African margins of the eastern Atlantic, apart from one Idas sp. collected from the Mediterranean ridge (Olu-Le Roy et al., 2004) and the report of "chemosynthetic mussels" in the Gulf of Cadiz (D. Masson et al. unpublished). However, recent ROV expeditions allowed us to discover dense populations of a large and very elongate bathymodioline mussel on a giant pockmark in the Gulf of Guinea named REGAB, which morphologically resembles the slender western Atlantic mussels $B$. heckerae and B. boomerang. Moreover, commercial trawling along the African margin off Banc d'Arguin, Mauritania, led to the sampling of Bathymodiolus mauritanicus Cosel 2002, presumably associated with methane cold seeps. This species displays morphological similarities with the Gulf of Mexico species Bathymodiolus childressi Gustafson, Turner, Lutz and Vrijenhoek 1998 and was included in the same morphological "group" by Cosel (2002). More recently, two species of mytilids were collected by box cores along the Nigerian margin, with one of them resembling B. heckerae and others being very close to B. mauritanicus or B. childressi (Cordes et al., 2007). This strong morphological resemblance despite the 
great transatlantic distance between the Caribbean seep sites and their African counterparts raises questions about the genetic similarity and the dispersal abilities of the western and eastern Atlantic mussels. Moreover, it generates hypotheses about the greater or lesser diversification of cold-seep species as opposed to the vent species over great spatial scales (i.e. the Atlantic equatorial belt vs. the MidAtlantic Ridge) (Figure 1).

In this paper, the morphologies of Bathymodiolus sp. B. and B. boomerang from the Barbados prism are first compared to B. mauritanicus and Bathymodiolus sp. A from the West African seeps and to other closely-related species from the Gulf of Mexico and the Florida Escarpment. Detailed phylogenetic studies using sequences of both the rDNA internal transcribed spacer (ITS2) and the mitochondrial cytochrome c oxidase subunit I gene (COI) of these species and of additional Nigerian specimens were then performed to confirm the hypothesis of a genetic relatedness between eastern and western Atlantic seep mussels.

\section{Materials and Methods}

\section{Sampling sites and animal collections}

The specimens used for new morphological and molecular studies, as well as previously published sequences included in phylogenetic analyses are listed in Table 1.

Specimens of the slender West African Bathymodiolus sp. A were sampled during the ZAIROV, BIOZAIRE I and BIOZAIRE II cruises by the ROV Victor 6000 on the REGAB site, a pockmark $900 \mathrm{~m}$ in diameter located 8 kilometers north of the Zaire canyon, at $3170 \mathrm{~m}$ depth (Ondréas et al. 2005). This site is characterized by high methane concentrations in the seawater and by blocks of methane hydrate protruding from the sediment (Charlou et al., 2004; Olu-Le Roy et al., 2007). Mussel beds occur in the most active part of the area, where methane percolates (up to $33 \mu \mathrm{M}$ close to the mussels) and carbonate concretions are abundant. Bathymodiolus sp. A forms dense beds (592-929 ind $\left./ \mathrm{m}^{2}\right)$, which range from a few meters to 30 meters in diameter (Olu-Le Roy et al., 2007). Five mytilid aggregates were selected for sampling, but no morphological differences have been noticed across the different sampling areas. The 
mussels were living on carbonate crusts or in depressions filled with soft sediment, or, rarely, they were isolated and partially buried in sediment. Bathymodiolus sp. A was found in close association with the siboglinid polychaete Escarpia southwardae Andersen, Hourdez, Marie, Jollivet, Lallier and Sibuet 2004. Two large species of vesicomyid bivalves also occur at the same REGAB site. The Barbados mussels, $B$. boomerang and the methanotrophic Bathymodiolus sp. B were collected together by the submersible Nautile from the Orénoque A diapiric ridge (both species), the Orénoque B Dome 13 (B. boomerang) and the El Pilar C Dome 2 (Bathymodiolus sp.B) during the DIAPISUB cruise. These sites and the seep ecology of B. boomerang are described in Olu et al. (1996) and Cosel and Olu (1998).

The five specimens of $B$. childressi used for ITS2 sequences were collected from two distinct localities of the Gulf of Mexico: "Brine Pool" along the Louisiana continental slope (Johnson Sea-Link dive A4038) and Alaminos Canyon together with two specimens of B. brooksi (Alvin dive A2209). Three specimens from $B$. heckerae were collected from the Florida Escarpment during the Alvin/AtlantisII cruise 2000. Specimens of Bathymodiolus thermophilus Kenk and Wilson 1985 were collected on the East Pacific Rise (EPR) with the submersible Nautile (HOT96 and NAUDUR cruise). Specimens of B. azoricus and $B$. puteoserpentis were collected along the Mid-Atlantic Ridge (MAR) with the Nautile (MARVEL and MICROSMOKE cruises). Specimens of Bathymodiolus brevior Cosel, Métivier and Hashimoto 1994 and Bathymodiolus elongatus Cosel, Métivier and Hashimoto 1994 were collected with the submersible Shinkai 6500 during the cruise Yokosuka 1991.

Previously published COI sequences were used in phylogenetic analyses, including two recently collected Bathymodiolus species from the Nigerian slope, one morphologically close to B. heckerae and hereafter referred to as B. sp Niger A, and one preliminarily assigned to B. cf mauritanicus (Cordes et al., 2007).

\section{Specimen preservation}

The specimens for dissection were fixed on board in $4 \%$ formaldehyde solution diluted in seawater and then transferred to $75 \%$ ethanol. The valves were kept gaping but care was taken that the adductors were 
not cut. The specimens for molecular work were directly preserved in $99 \%$ ethanol, frozen, or preserved in BLB (1M Tris-HCl, 0.5M EDTA, 10\% SDS pH 8.0).

\section{Molecular analyses}

Two molecular markers were used to establish the phylogenies of the species: the non-coding transcribed spacer (ITS2) separating the $5.8 \mathrm{~S}$ and $28 \mathrm{~S}$ ribosomal genes as it is assumed to be neutral and to evolve at a high rate in invertebrates (1-1.2\% substitutions per Myr: Schlötterer et al. 1994) and the often-used mitochondrial cytochrome oxidase I (mtCOI) for which additional sequences were obtained from GenBank from earlier studies (Table1).

\section{DNA extraction}

Tissue samples (10-50 mg) of Bathymodiolus specimens were digested overnight with proteinase $\mathrm{K}$ at $55^{\circ} \mathrm{C}$ in $0.5 \mathrm{ml}$ PK-SDS lysis buffer (Tris-HCl $50 \mathrm{mM} \mathrm{pH} \mathrm{8.0,} \mathrm{NaCl} 100 \mathrm{mM}, 10 \mathrm{mM}$ EDTA, 1\% SDS). Genomic DNA was then extracted using a standard phenol/chloroform protocol and precipitated with ethanol. The pellet was resuspended and stored at $4{ }^{\circ} \mathrm{C}$ in TE (10 mM Tris, $1 \mathrm{mM}$ EDTA pH 8.0$)$ for amplifications.

\section{rDNA ITS spacer sequencing}

The non-coding transcribed spacer (ITS2) was first amplified using a set of "universally" applicable primers designed by P.W.H. Holland and associates from a wide range of metazoan sequences (see Jollivet et al. 1998):

PH19 5' -CATC GACA CTTT/C GAAC GCA- 3'

ITS2 5' -AATC CTGG TTAG TTTC TTTT CCTC CGCT- 3'

and then with nested primers specifically designed for the genus Bathymodiolus:

BathF 5'-GCTTAAATTCAGCGGGTACT-3'

BathR 5'-ACATTGCGGCTTTGGGTCAC-3' 
Amplification reactions were performed using a Perkin-Elmer GenAmp 9700 Robot-Cycler in a 25- $\mu 1$ reaction volume consisting of $1 \mathrm{X}$ PCR buffer; $2 \mathrm{mM} \mathrm{MgCl} 2 ; 0.12 \mathrm{mM} \mathrm{dNTPs} ; 0.2 \mu \mathrm{M}$ forward and reverse primers; $0.5 \mathrm{U}$ of Thermoprime Plus Taq polymerase (ABgene); and $25 \mathrm{ng}$ genomic DNA. The optimal PCR cycling parameters were a first step of $3 \mathrm{~min}$ at $96^{\circ} \mathrm{C}$ followed by 35 cycles: $1.15 \mathrm{~min} / 50^{\circ} \mathrm{C}$, $1 \mathrm{~min} / 72^{\circ} \mathrm{C}, 1 \mathrm{~min} / 96^{\circ} \mathrm{C}$ and 1 cycle of $2 \mathrm{~min} / 50^{\circ} \mathrm{C}$ and $10 \mathrm{~min} / 72^{\circ} \mathrm{C}$. PCR products were visualized on 2\% agarose gels containing ethidium bromide under UV light. PCR products were purified using a QIAquick $^{\mathrm{TM}}$ PCR purification kit, T/A-end ligated into a BlueScript ${ }^{\mathrm{TM}}$ T-vector plasmid at $16^{\circ} \mathrm{C}$ overnight, and subsequently cloned into DH5 $\alpha$-competent cells. Positive clones were screened by PCR using vector-specific primers flanking the insertion site. Plasmids were then used as a template for sequencing. Both DNA strands were sequenced for at least three distinct clones per individual (more if the three clones differed in sequence) using either T3 or T7 TexasRed primers. Fragments were subjected to electrophoresis on a 5\% Hydrolink Long Ranger ${ }^{\mathrm{TM}}$ gel on a 725 VISTRA $^{\mathrm{TM}}$ DNA sequencer.

\section{Direct sequencing of $m t C O I P C R$ products}

Partial sequences (ranging from 595 to $630 \mathrm{bp}$, depending on species) of the mitochondrial cytochrome oxidase subunit I gene (mtCOI) were obtained using specifically designed primers:

\section{BathCOI-F: 5'-TGTGGTCTGGAATAATTGGAAC-3'}

\section{BathCOI-R: 5'-ATAAAAAGATGTATTRAARTGACG- 3'}

based on an alignment of a few bathymodiolin sequences previously obtained with the 'universally' applicable primers described by Folmer et al. (1994). DNA amplifications were performed under the following conditions: an initial denaturation step at $94^{\circ} \mathrm{C}$ for 2 min followed by 5 cycles: $35 \mathrm{~s} / 94^{\circ} \mathrm{C}$, $35 \mathrm{~s} / 48^{\circ} \mathrm{C}$ and $70 \mathrm{~s} / 72^{\circ} \mathrm{C}$ followed by 35 cycles: $35 \mathrm{~s} / 94^{\circ} \mathrm{C}, 35 \mathrm{~s} / 52^{\circ} \mathrm{C}, 70 \mathrm{~s} / 72^{\circ} \mathrm{C}$ and a final elongation at $72^{\circ} \mathrm{C}$ for $10 \mathrm{~min}$. PCR reactions were performed into a $25-\mu 1$ reaction volume consisting of $1 \mathrm{X}$ PCR buffer; $2 \mathrm{mM} \mathrm{MgCl} 2 ; 0.12 \mathrm{mM}$ dNTPs; $0.2 \mu \mathrm{M}$ of forward and reverse primers; $0.5 \mathrm{U}$ of Thermoprime Plus Taq polymerase (ABgene); and 25 ng genomic DNA. The PCR products were then purified and 
directly sequenced on an ABI 3100 automated sequencer using BigDye ${ }^{\odot}$ (Perkin Elmer) terminator chemistry.

\section{Sequence analyses}

Sequences used in phylogenies were selected according to three main criteria: (1) performing ITS2 and COI trees with the same species in order to compare them more accurately, (2) collecting a maximum of sequences for species suspected of belonging to the two complexes under study and, (3) getting a few morphologically distinct vent/seep species as a reference to assess species divergence. Forward and reverse sequences were proofread in Trace Viewer and corrected manually using Se-Al 2.0 Sequence Alignment Editor (Rambault, 1996) after being automatically aligned using ClustalX (Thompson et al. 1997). Both 472 bp rDNA ITS2 and 380 bp mtCOI sequence alignments were used to produce ML, MP and NJ phylogenetic trees with the PAUP 4.0b software (Swofford, 2002), using all informative sites and gaps when present and visualized using TreeView (Page, 1996). Substitution models used in phylogenies were selected according to Modeltest 3.7 (Posada and Crandall, 2001) with the Bayesian Information Criterion (BIC) at a level of significance $\alpha$ of 0.01 . K2P distances were obtained using the DNAdist package of PHYLIP 3.573 (Felsenstein, 1981) to calculate frequency distributions of pairwise COI sequence differences in order to test for geographically-differentiated population admixture in both complexes of species. Sequence saturation was graphically tested from our dataset by plotting transitions versus transversions for the non-coding ITS2 region and by plotting the K2P (first two codon positions) versus the K2P (all three codon positions) for mtCOI (coding sequence).

\section{Ribosomal ITS2}

The neighbor-joining tree was obtained using the K2P distance (Kimura, 1980) and 10, 000 resampling bootstraps. The MP tree was obtained using the Branch-and-bound search approach with a furthest sequence addition procedure. Because gaps were numerous and found informative, they were treated as a fifth base. Each gap, however, was weighted as a single substitution. The optimal parsimony criterion was 
that of Goloboff fit $(\mathrm{K}=2)$. An additional bootstrap 50\% majority-rule consensus MP tree was obtained using a heuristic approach and 100 resampling bootstraps. For each dataset resampling, starting trees were obtained via stepwise addition as the closest and branches were furthermore swapped using the treebisection-reconnection (TBR) algorithm. Branches creating polytomies were collapsed if maximum branch length was equal to zero.

\section{Mitochondrial COI gene}

The neighbor-joining (NJ) tree was obtained using the K2P distance and 10000 resampling bootstraps using the BIONJ algorithm for either the three codon positions or only the first two codon positions. The maximum likelihood tree was obtained from a heuristic approach using the HKY85+G model (Hasegawa et al. 1985) selected by Modeltest $3.7(-\mathrm{LnL}=1662.4, \mathrm{~K}=96, \mathrm{BIC}=3895.06)$ and a rate of substitution assumed to follow a gamma distribution ( 4 rate categories, $\alpha=0.1855$ ). The search for the best tree was performed using a tree-bisection-reconnection (TBR) branch-swapping algorithm. Starting trees were obtained via stepwise addition with a random sequence addition (10 replicates) with starting branch lengths obtained using the Rogers-Swofford approximation method. The subsequent ML topology was then tested using a bootstrap method with a fast-heuristic search and 100 replicates following the same model parameters (i.e. $\mathrm{HKY}+\mathrm{G}$ model).

Because Jones et al. (2006) found that methylotrophic symbiont-bearing mussels and thioautotrophic symbiont-bearing mussels represent 'true' monophyletic clades, all trees were rooted using the midpoint rooting method (B. childressi complex of species vs. other vent/seep mussels). This allowed us to exclude external mytilid outgroups (e.g. Tamu fisheri or Modiolus modiolus) that are far too divergent in order to avoid nucleotidic saturation and long-branch attraction.

\section{Results}

Morphological descriptions 
Bathymodiolus sp. A from the REGAB site in the Gulf of Guinea has a thin and very elongate shell with a narrowly rounded anterior margin and a broadly rounded posterior margin (Figure 2). The ventral margin is straight in young individuals, becoming more and more concave in larger specimens. The anatomy of the soft parts is indistinguishable from that of B. boomerang and B. heckerae: the foot-byssus retractor muscle complex extends with the shell but the anterior byssus retractor is short. The posterior bundle of the posterior byssus retractor is very long and thin and passes at a very low angle (about $15^{\circ}$ ) from the longitudinal shell axis towards the attachment point in the postero-dorsal part of the valves next to the adductors. The heart is located in the posterior part of the body, the digestive tube is simple, the stomach is small, and the midgut runs straight and median from the stomach towards the posterior end to under the ventricle, entering it without any coiling or loop.

Shell shape and soft-part morphology place this mussel in the B. heckerae group, as defined by Cosel (2002). Because of the anteriority of the description of B. boomerang, however, we refer to this group as the $B$. boomerang complex hereafter. According to the size of the individuals, which have a straighter than concave antero-ventral margin, the morphologically closest species is B. heckerae from the Florida Escarpment (Figure 4) and the REGAB mussel was therefore treated as Bathymodiolus aff. heckerae in previous literature (Duperron et al., 2005, Ondréas et al., 2005). The only difference between the Gulf of Guinea specimens and B. boomerang (Figure 3) is the absence of very large individuals, which have a more pronounced "boomerang" shape, a more concave antero-ventral margin and a more broadly rounded anterior margin. However, an empty broken shell of about $300 \mathrm{~mm}$ and a height of $88 \mathrm{~mm}$ was sampled during the ZAIROV 2 cruise on another pockmark located south of the Zaire canyon at about 10 miles from the REGAB site and at $1900 \mathrm{~m}$ depth (K. Olu, R. von Cosel, A. Ondréas unpubl. data). The maximum known length of $B$. heckerae specimens from the Florida Escarpment is $230 \mathrm{~mm}$ as documented by Van Dover et al. (2003), whereas the largest B. boomerang was $360 \mathrm{~mm}$ in length (Cosel and Olu 1998). The largest skewed specimen of B. heckerae from the Blake Ridge diapir, however, had a length of $364 \mathrm{~mm}$ (Van Dover et al., 2003) and thus equals the size of B. boomerang. Apart from the size, 
the shape variability is about the same across the four localities (Florida Escarpment, Barbados, Blake Ridge and Gulf of Guinea) with no morphological difference between them.

Bathymodiolus sp. B from the Barbados prism (Figures 5 and 6) has a short and stout shell that is variable in outline, is up to $127 \mathrm{~mm}$ long, and varies from rather thin but solid to thick-shelled. Juvenile specimens are broader still and less tumid than adults. Length-height ratio is 1.77 . The beaks are slightly subterminal, at one-twelfth to one-fifteenth of the total shell length. The anterior margin is more or less narrowly rounded, and the ventral margin in adult specimens is markedly concave in the middle part, occasionally with a crease-like concave angle. The posterior margin is ventrally more or less broadly rounded, with the postero-dorsal margin slightly to markedly convex; the postero-dorsal corner is rather broadly rounded. The umbones are broad and somewhat flattened, the ligament plate slightly arched to nearly straight. The anterior adductor scar is small and placed just in front of the umbo. The large posterior adductor scar is united with the scar of the multibundle posterior pedal and byssus retractor muscle. The anterior byssus retractor scar is located in the posterior part of the umbonal cavity, behind the beaks. The larval shell is 200 microns long and high, circular, purplish red and sharply separated from the whitish postlarval shell. The foot-byssus retractor muscle complex has a rather long anterior retractor. The posterior byssus retractor is short and consists of two very strong muscle bundles, which are close together. The heart has large auricles that are fused posteriorly but for a short distance, and the ventricle is small and rather narrow. The stomach is very small and elongate, with extremely thin walls, and hardly recognizable chambers; style sac and midgut are conjoined. The midgut runs midline towards under the ventricle, changing direction there twice in a short S-shaped curve that is directed towards dorsal and slightly to the right side before entering the ventricle.

Slight differences in outline and inner mantle fold features were observed between Bathymodiolus sp. B specimens from Orenoque A sector and El Pilar sector, separated by a distance of about $150 \mathrm{~km}$. The anterior end with umbo in the El Pilar specimens is somewhat narrower, and the shells are shorter. In most juveniles from the El Pilar domes there is a weak papilla on the valvular siphonal membrane, as in 
B. childressi, whereas in all the specimens from the Orenoque sector, the margin is smooth. El Pilar specimens are generally smaller than specimens from Orenoque, with mean shell lengths of 54.9 and 92.2 $\mathrm{mm}$, respectively. Comparison of allometric curves between 51 individuals from each locality showed slight differences in growth; individuals from Orenoque become stouter with increasing length than specimens from El Pilar. These differences are also well represented using the length-height (1/h) ratio versus shell lengths (Figure 7), but 1/h ratios (sub-samples of 51 specimens of various sizes for each site) were significantly different between sites according to both the non-parametric Mann-Whitney U-test $(\mathrm{p}=0.02)$ and the Kolmogorov-Smirnov test $(\mathrm{p}=0.037)$. Length/tumidity ratios were, however, not significantly different. Additional measurements of the anterior part length (i.e. length from the anterior margin to the umbo) evidenced much shorter (about half as long) anterior parts for El Pilar specimens; differences were highly significant according to Student test $\left(\mathrm{p}=2.710^{-7}\right)$ and Mann - Whitney U test $\left(\mathrm{p}=2.210^{-11}\right)$.

Species of the $B$. childressi group as defined by Cosel (2002) differ from each other by weak but consistent differences. The shell of Bathymodiolus sp. B from Barbados varies from modioliform, as in $B$. childressi, to more wedge-shaped, as in B. mauritanicus (Figure 8). The thickness of the shell in most observed specimens is also intermediate between the thin shell of $B$. childressi and the rather thick shell of $B$. mauritanicus. The position of the umbones is slightly subterminal to terminal, like those of $B$. childressi, whereas they occupy a terminal position in B. mauritanicus. Bathymodiolus sp. B from Barbados shares with other species of the $B$. childressi group an adult hinge line that is thickened below and anterior to the umbones, but it is shorter than in B. childressi, B. mauritanicus, and Bathymodiolus platifrons Hashimoto and Okutani 1994, another species of this group. The posterior end of the ligament is abrupt, as in B. childressi, whereas it is tapered in B. mauritanicus. The comparison of shells among species of the B. childressi group suggests that Bathymodiolus sp. B from Barbados and B. childressi differ less from each other than they do from B. mauritanicus. However, some characters are shared by Bathymodiolus sp. B and B. mauritanicus and not by B. childressi, e.g. small anterior adductor scar, a continuous posterior retractor scar and a very posteriorly-located anterior retractor scar. Moreover, the 
fact that some individuals of both B. mauritanicus and Bathymodiolus sp. B have very thick and strong shells for their size is not common in bathymodiolin mussels. Finally, soft parts have been compared to those of B. childressi and B. platifrons only, as the animal of B. mauritanicus was not available. The papilla in the middle of the valvular siphonal membrane is almost absent in specimens from Barbados, as in B. childressi. It is, however, present in B. platifrons, as in the B. thermophilus, B. heckerae and B. brevior groups. The intestine lacks a short loop, as in B. childressi, but is short-S-shaped and not straight, as in B. platifrons or other Bathymodiolus spp. The form of the intestine is, however, highly variable in the Bathymodiolinae and is likely dependent on the balance between filter feeding and symbiosis in nutrition.

\section{Molecular analyses}

\section{Mitochondrial COI gene}

Accession numbers for new COI sequences are given in Table 1. The two trees yielded essentially the same topologies, with the exception of deep branches that were poorly supported (low boostrap values). Only one tree is presented here with bootstrap values for both Neighbor Joining and Maximum Likelihood (ML) methods(fig. 9). Both trees indicate the occurrence of two well-supported complexes of species within which the level of divergence did not exceed 0.05 . Using only the first two codon positions in the analysis (not shown) produced a similar topology but with less resolution within the clades. The maximum likelihood tree was obtained (Likelihood tree: $\mathrm{LnL}=-1481.38895$, Figure 9) with a number of distinct data patterns of 100 under the $\mathrm{HKY}+\mathrm{G}$ model over the 380 bases (sequence length) with no invariable sites and a gamma distribution shape parameter of 0.1855 . Estimated base frequencies revealed a large excess of $\mathrm{T}(\mathrm{A}=0.2225, \mathrm{C}=0.1595, \mathrm{G}=0.1902$ and $\mathrm{T}=0.4277)$, with an estimated $\mathrm{Ti} / \mathrm{Tv}$ ratio = $5.0391($ kappa $=11.05)$. The two major clades $($ average K2P distance between clades $=0.18)$ correspond to the B. childressi complex of species on the one hand (all the species that are strictly symbiotic with methanotrophic bacteria) and the B. boomerang complex of species on the other hand (comprising all the seep species with both sulfide-oxidizing and methanotrophic symbiotic bacteria). The African species $B$. 
mauritanicus and specimens collected along the Nigerian coast all fall within the clade containing the methanotrophic Bathymodiolus sp. B (Barbados). This clade is closely related to B. childressi from the Gulf of Mexico but differs by 9 transitions and 1 transversion, (K2P distances ranged from 0.023 and 0.035.) COI sequence data indicate that the cluster B. mauritanicus/Bathymodiolus sp. B is genetically isolated from B. childressi. Within the group of B. childressi, sequences from the deepest site (Alaminos Canyon) differed by one transition from the shallower sites (Bush Hill, GC234, MS_Canyon). The K2P frequency histograms obtained for the $B$. childressi complex of species with and without $B$. childressi (Figure 10) showed that this complex of species represents an admixture of geographically isolated populations. Indeed, the histogram is clearly bimodal when B. childressi is included. In this figure, the peak centered at 0.03 (black circles) represents all pairwise differences between $B$. childressi and the other species. When B. childressi individuals are removed (white circles), a small peak remains but is not attributable to geographical differences between the African and Barbados mussels, suggesting that these latter mussels could represent a valid amphi-Atlantic species.

In species with sulfide-oxidizing symbionts, morphologically distinct species display K2P distances close to 0.15 with the exception of B. heckerae, B. boomerang and mussels collected from the Gulf of Guinea and Nigeria, which form a homogeneous clade (inter-specific K2P distances $<0.02$ ). The species $B$. heckerae, however, derived from this group by 3 transitions and 1 transversion. Given the low number of sequences for this species we cannot state whether it represents a true homogenous group. The two fixed differences between B. boomerang and Bathymodiolus sp. A sequences suggest that these mussels are at least isolated from each other. The $\mathrm{K} 2 \mathrm{P}$ frequency histograms obtained for the $B$. boomerang complex of species with and without $B$. heckerae (Figure 11) also confirmed that populations from the Florida Escarpment are genetically isolated from their southernmost amphi-Atlantic counterparts. In contrast to $B$. childressi, the histogram remains clearly bimodal after the removal of the two individuals of $B$. heckerae with a peak centered around 0.01. This peak encompasses all pairwise differences between African and Barbados mussels and thus indicates that there is a less pronounced, but still manifest, genetic break between mussels across the Atlantic when compared to the B. childressi complex of species. 


\section{Ribosomal ITS2}

Because phylogenetic relationships between bathymodiolin mussels cannot be restricted to the mitochondrial genome as it is very often subjected to selective sweeps (Bazin et al., 2006) and thus prone to adaptive radiation, the validity of species complexes has also been assessed using a nuclear marker that presents an evolutionary rate nearly similar to the COI gene. The accession numbers for ITS 2 sequences are given in Table 1. Both phylogenetic methods essentially provide the same tree topologies except for deep branches that are supported by low bootstrap values. The best Maximum Parsimony (MP) tree (Goloboff fit $=-70.929)$ was obtained based on 456 characters (gaps included) from which 346 were invariant, 27 were variable but not found informative, and 81 were parsimony-informative (Figure 12). The tree is characterized by good consistency (CI) and retention (RI) indices of 0.709 and 0.895 , respectively. The tree presented in figure 12 displays bootstrap values obtained from both the NJ and MP methods. As for the COI phylogeny, this tree supports the occurrence of the two species complexes corresponding to the $B$. childressi $(0<\mathrm{K} 2 \mathrm{P}$ distances $<0.028)$ and $B$. boomerang $(0<\mathrm{K} 2 \mathrm{P}$ distances $<$ $0.015)$ clusters that were previously reported with the mtCOI gene. However, it indicates the occurrence of two distinct species within $B$. brooksi and also seems to support the occurrence of types a and b (shallow and deep, respectively) within the B. childressi sequences . The individual Bchildb2 is found in both clusters and could correspond to a hybrid. The inclusion of the gaps as a fifth character greatly improved the resolution of the phylogenetic signal across bathymodiolin species and led to a single MP tree with higher bootstrap values. Grouping strongly suggests that Bathymodiolus sp. B (Barbados) corresponds to B. childressi, with one individual from Orenoque area falling within $B$. childressi type a and the other from El Pilar in B. childressi type b. Within the B. boomerang clade, B. boomerang is well separated from $B$. heckerae/B. sp. A (from Africa) by a clear indel signature and 3 transversions, whereas B. heckerae seems to derive from $B$. sp. A by only one transition.

Interestingly, B. puteoserpentis does not form a sister group of B. azoricus, as was expected from the COI phylogeny. However, this sequence was found only in a single individual when the other individuals 
yielded typical B. azoricus sequences. This could indicate either the presence of a cryptic species, the persistence of an ancient lineage in the B. puteoserpentis allele coalescent, or the occurrence of a selective sweep that favored the spread of the B. azoricus allele in the B. puteoserpentis population.

\section{Discussion}

Occurrence of two amphi-Atlantic Bathymodiolus species complexes

Morphological and phylogenetic analyses of Bathymodiolus species from several cold seeps across the Atlantic - the tropical West African and the Caribbean zoogeographic provinces - revealed the occurrence of two amphi-Atlantic species complexes: the B. childressi complex and the B. boomerang complex. This shows a clear connection between cold-seep communities from Barbados and the Gulf of Mexico on the one hand, and between these Western Atlantic areas and the tropical West African province on the other. These species complexes are representative of two major clades of the genus Bathymodiolus, one hosting a symbiosis strictly with methanotrophic bacteria (the B. childressi complex) and the second displaying dual symbioses with both methanotrophs and sulfide-oxidizers (the B. boomerang complex). Based on morphological characters of shell and soft parts of the mussels, these two main groups have already been described by Cosel (2002) and are referred to as the B. childressi and the B. heckerae/B. boomerang groups. Most speciation events appear to be fairly recent within both clades and suggest a concomitant history of colonization in the Atlantic Ocean that probably occurred during the last Miocene-Eocene tectonic reorganization of the Panama seaway (Coates and Obando, 1996, Roth et al., 2000).

In the present paper, the molecular examination of the recently-discovered long and slender seep mytilid from the Gulf of Guinea (Bathymodiolus sp. A) clearly assigns it to the B. boomerang complex. Apart from the size, there is no obvious morphological difference to discriminate among specimens from the three geographic areas. Shell morphology is almost the same in the three populations. This finding supports well the occurrence of a widespread complex of cold-seep species that clearly represents a sister group to the vent species $B$. azoricus, which possesses a dual symbiosis. Interestingly, based on a 
bacterial 16S phylogeny, Duperron et al. (2005) also reported that the methanotrophic symbiont of Bathymodiolus sp. A (Africa) is most closely related to the symbiont of $B$. heckerae (Florida Escarpment). Larger series of adult specimens are necessary, however, before we can assign the African specimens to B. boomerang. Indeed, molecular analyses do not strictly support the hypothesis of an amphi-Atlantic species. Within the B. boomerang clade, phylogenetic trees based on mtCOI clearly separate B. heckerae from Bathymodiolus sp. A (Africa) and B. boomerang from Barbados. Based on the ITS2 marker, the phylogeny suggests a slightly different interpretation in which $B$. heckerae differs from Bathymodiolus sp. A by only one transition but clearly differs from B. boomerang by three transversions and one indel. K2P frequency histograms also indicate that the B. boomerang complex is not homogeneous and is probably composed of genetically-isolated groups of individuals that correspond to B. heckerae on the one hand, and to B. boomerang/Bathymodiolus sp. A, on the other. The occurrence of few fixed differences between Barbados and African mussels therefore suggests at least the existence of isolated populations of a single species or sibling species in which $B$. heckerae derives from $B$. boomerang.

The genetic examination of the $B$. childressi species complex led to similar conclusions and supports the hypothesis of vicariant patterns of colonization between the two seep mussel complexes. Although slight morphological differences do exist, the mtCOI marker was not able to discriminate B. mauritanicus and the two B. aff. mauritanicus (Nigerian slope) from Bathymodiolus sp. B (from Barbados). However, $B$. childressi seems to be genetically isolated from its two related counterparts based on mitochondrial, but not nuclear, data. Such a discrepancy between the mitochondrial and nuclear genome evolution is not too paradoxical since the former has been shown to evolve faster. These latter populations therefore fall into the B. childressi complex, as defined by Cosel (2002), which also includes B. platifrons from vent sites in the western Pacific back-arc basins and represents a morphologically quite homogeneous group, which is also supported by genetic data (Miyasaki et al., 2004; Jones et al., 2006; Jones and Vrijenhoek, 2006). This group clearly differs from other Bathymodiolus species by several characters such as a small adductor scar, an almost continuous posterior byssus retractor scar, rather low and almost terminal 
umbones, and an anterior retractor scar positioned more posteriorly within the umbonal cavity compared to B. puteoserpentis, B. azoricus or B. thermophilus (Cosel, 2002). Within this complex, B. mauritanicus and Bathymodiolus sp. B are very close and well separated from B. childressi from the Gulf of Mexico. In contrast, phylogenetic trees based on the ribosomal internal spacer (ITS2) indicate that Bathymodiolus sp. B belongs to the species B. childressi which, in turn, represents a dichotomic clade, supporting the occurrence of morphological types a and b as previously proposed by Gustafson et al. (1998). This result does not agree with another recent genetic study (Carney et al., 2006), which reported no genetic differentiation between $B$. childressi populations using microsatellites and RFLP markers in the Gulf of Mexico. Such a discrepancy may be explained by hybridization patterns. Indeed, at least one individual contained both an ITS2 type "a" allele and an ITS2 type "b" allele, suggesting hybridization between the two morphs. On the Barbados accretionary prism, the Orenoque and the El Pilar mussel populations exhibit slight differences in morphology and significant differences in the shell shape. Past exchanges across the Caribbean zone may thus have been interrupted over a wide area, leading to the emergence of two B. childressi ecotypes that hybridized later on.

Morphological differences are not very marked but are consistent within the B. childressi complex when compared to other Bathymodiolus spp. (Cosel 2002). These small differences in shell characteristics were used for the taxonomic description of B. mauritanicus (Cosel, 2002). The shell comparison between species of the B. childressi complex indicates that Bathymodiolus sp. B (from Barbados) and $B$. childressi share some shell characteristics that differ in B. mauritanicus. They both have a more modioloform shape, a broader anterior part, and a less terminal position of umbones than $B$. mauritanicus. These observations are consistent with the ITS2 phylogeny in which Bathymodiolus sp. B is more closely related to B. childressi. It is, however, noteworthy that African specimens collected for phylogenetic purposes (including B. mauritanicus) were not collected from the type locality of $B$. mauritanicus.

Morphological similarities between the two Caribbean species are balanced by some other characters shared by Bathymodiolus sp. B and B. mauritanicus, and not by B. childressi. Although specimens from 
Barbados display a shorter hinge, the two latter species are characterized by a small anterior adductor scar, a continuous posterior retractor scar, and a very posteriorly-located anterior retractor scar. The two species also have a heavier and thicker shell than B. childressi from the Louisiana Slope. B. childressi seems to represent a distinct species when the mtCOI gene and some shell characteristics are considered. The nuclear marker ITS2, however, seems to group B. childressi and B. sp. B (Barbados). Therefore we cannot rule on the existence of distinct species in this complex without additional phylogenetic and morphological data.

\section{Trans-Atlantic similarities: recent colonization routes or long-distance larval dispersal?}

The lack of clear genetic differences between mussel populations in the Atlantic within the two species complexes indicates past connections between the western Atlantic and eastern Atlantic seep fauna and may support the hypothesis of recent exchanges between these geographically well-isolated populations, at least along the Atlantic equatorial belt. These colonization pathways appear clearly different from those that led to the colonization of the Mid-Atlantic Ridge and the emergence of B. azoricus and $B$. puteoserpentis, and they unambiguously show that hydrothermal vent fields from the MAR could not have acted as stepping stones across the Atlantic for the seep mussels. Three non-exclusive hypotheses may explain the occurrence of amphi-Atlantic species: (i) the occurrence of contemporary gene flow across the Atlantic equatorial belt via teleplanic larvae or larval exchanges along a continuum of seepages, sunken wood or whale carcasses, (ii) the very recent colonization of the Atlantic by the modern seep fauna via transform faults that offset the Mid-Atlantic Ridge and connect the western and eastern deep oceanic basins of the Southern Atlantic or (iii) the reflection of an evolutionary slow-down that prevented mussel lineages from diverging rapidly after they separated. The second and the third hypotheses may represent a valid explanation for species associated with cold seeps and have been previously invoked to reconcile paleontological and molecular data for vestimentiferan tubeworms (Little and Vrijenhoek, 2003). Chevaldonné et al. (2002) used Northern and Eastern Pacific sibling species to calculate the mtCOI substitution rate of vent annelids and found that it could be one order of magnitude 
lower $(0.2 \%$ per Myr) than that of vicariant coastal/intertidal Panamanian species (Knowlton and Weigt, 1998). Based on this kind of estimate, Jones et al. (2006) proposed that species diversification is recent in the genus Bathymodiolus and may have occurred during the progressive closing of the Panama Seaway, 10 to 3 M yrs ago (Ross and Scotese, 1988; Coates and Obando, 1996). This closing may have seriously affected both bottom and intermediate water circulation (Haddad and Droxler, 1996; Roth et al, 2000) and could have thus reinforced transverse circulation between eastern and western Atlantic basins along the equatorial belt, which in turn might have promoted migration across the Atlantic and the concomitant diversification of the genus Bathymodiolus, at least in the Atlantic. This view is supported by Gill et al. (2005), who reported the occurrence of bathymodioline mussels in the Eocene-Miocene carbonates of the Caribbean region. Interestingly, two siboglinid species, Escarpia spicata (Pacific coast of North America) and E. laminata (Gulf of Mexico) display very low levels of mtCOI divergence despite their isolation across the Panama Isthmus, suggesting that the substitution rate is extremely low in at least some seep species (McMullin et al., 2003).

The first hypothesis involves effective exchanges of propagules in the Atlantic Equatorial Belt. In highly fragmented and unstable environments, long-lasting larvae are a key element to ensure the efficient recolonization of patchy habitats and thus a powerful tool to minimize the risk of a species becoming extinct. To date, dispersal capabilities of deep-sea organisms have been indirectly estimated for the vent fauna only, based on reproductive studies, larval transport models, and genetic structure (Mullineaux and France, 1995; Chevaldonné et al., 1997; Vrijenhoek, 1997; Comtet et al., 2000; Mullineaux et al., 2000, 2005; Marsh et al., 2001). The ability of vent species to recolonize new sites clearly shows their great potential for long-distance dispersal capabilities (Tunnicliffe et al., 1997; Shank et al., 1998). This assumption is in agreement with the lack of genetic structure that has been observed for numerous vent taxa over oceanic ridge scales (Jollivet, 1996). Effective larval transport across the Atlantic requires that larvae stay long periods of time in the water column. Generally speaking, more than $80 \%$ of marine invertebrates that possess a planktotrophic larva have an amphi-Atlantic distribution, and this is the case for, respectively, 10 and $30 \%$ of mollusks of the eastern Atlantic or from both coasts (Cosel, 1982; 
Vermeij, 2005), with some being "pseudo amphi-Atlantic", using islands as "stepping stones" and "real" amphi-Atlantic species, with long-distance planktonic larvae. Bathymodiolus possesses a protoconch I of about $100-120 \mu \mathrm{m}$ and a protoconch II of $380-520 \mu \mathrm{m}$ long, supporting the idea of a long planktonic phase (Cosel et al., 1994; Cosel and Olu, 1998), with a duration of the free-swimming larval phase comparable to that of the blue mussel (Bayne 1965). Experiments on B. childressi larvae or indirectly on the reproductive dynamics of $B$. azoricus suggested that larvae can remain in the plankton for 5-6 months (Berger and Young, 2006; Tyler et al., 2005; Dixon et al., 2006).

In contrast to oceanic ridges, where negatively-buoyant larvae can easily be channeled by currents over great distances inside the axial valley (Mullineaux and France, 1995; Chevaldonné et al., 1997; Metaxas and Giffin, 2004), larval transport across deep oceanic basins seems more uncertain for the seep fauna. The Antarctic Bottom Water (AABW) enters the Guinea basin via the Romanche Fracture Zone and the Chain Fracture Zone (Mercier and Speer, 1998; Stephens and Marshall, 2000). The Brazil basin represents a vortex zone from which the AABW is subdivided into additional jets that move northward against the western flank of the Mid-Atlantic Ridge to reach the Florida Escarpment (Amos et al., 1971) and enters the Mid-Atlantic Ridge using the Vema Fracture Zone (Heezen et al., 1964; Stephens and Marshall, 2000). Longitudinal flow and movement of North Atlantic Deep Water (NADW) flowing between 1200 and $4000 \mathrm{~m}$ (Arhan et al., 1998) may represent a relay for long-lasting propagules. However, this deep current and stronger intermediate jets extending more broadly on both sides of the Atlantic (Arhan et al., 1998; Bourles et al., 2003; Schmid et al., 2005) have very low velocities (2-3 $\mathrm{cm} \mathrm{s}^{-1}$ and $10 \mathrm{~cm} \mathrm{~s}^{-1}$, respectively) that theoretically would not allow west-east particle transport in less than a few years (Richardson and Fratantoni, 1999; Andrié et al., 2002). The role of time-variable components, mixing, and eastward extra-equatorial jets is nevertheless unknown, and the transport times could be much lower than those predicted by models (Arhan, pers.com.). In contrast, shallower currents can be orders of magnitude faster, e.g. 0.8 to $1 \mathrm{~m} \mathrm{~s}^{-1}$ for the equatorial counter-current (Weiberg et al., 1987), representing crossing times of a few months, closer to the residence time of larvae in the water column. It is not known whether the larvae remain at the depth where the adults live. The larvae may very well get 
close to the surface. Siboglinid larvae were indeed captured at depths as shallow as 5, 90 and $110 \mathrm{~m}$ (Marie et al., 2006). The temperature may be not a limiting factor for upward migration, high thermal tolerance (up to $20^{\circ} \mathrm{C}$ ) having been observed in adult B. childressi and other seep gastropods (Van Gaest and Young, 2005; Berger and Young, 2006).

Other invertebrate species sampled at the REGAB site (Congo seeps) have close relatives at seep sites in the Caribbean province. The Alvinocaris shrimp is morphologically and genetically (COI) indistinguishable from Alvinocaris muricola Williams 1988 initially described from the Florida Escarpment (Komai and Segonzac, 2005; Hourdez, unpublished data). The vestimentiferan tubeworm Escarpia southwardae, also from REGAB, displays less than $0.2 \%$ divergence in COI with its escarpiid relatives from the Gulf of Mexico (Andersen et al., 2005). The commensal polynoid found in Bathymodiolus sp. A is genetically similar to Branchipolynoe seepensis Pettibone 1986 occurring at the Florida Escarpment (D. Jollivet, unpublished data). Finally, other deep-sea species such as the galatheid Munidopsis geyeri Pequegnat and Pequegnat, 1970 or the holothurian Chiridota heheva Pawson and Vance 2004, known from the Gulf of Mexico, the Columbia and Venezuela Basins, or the Florida Escarpment seeps, have also been sampled on seeps of the African margin (Pawson, 2004; MacPherson and Segonzac, 2005).

Other reduced environments may also act as stepping stones for larvae of amphi-Atlantic seep species. While sunken wood and whale falls are probably less common when moving away from the continental shelves, it remains plausible that low-temperature vents or seeps occur along the transform faults crossing the MAR or along the ridge itself (D. Desbruyères, pers. comm.). Hydrothermal activity may also occur in pronounced transform valleys (German et al., 1996) and may serve as stepping stones for dispersal (Van Dover, 2002). Dense beds of large Vesicomyidae have already been observed in the VEMA transform fault (M. Segonzac, pers. comm.), and other active fluid seeping areas have been observed offaxis along the MAR (Y. Fouquet pers. comm.). Some faunal exchange between MAR vents and seeps of 
both the Gulf of Mexico and Barbados prism seems to occur as suggested by the sampling of the same species of ophiurids at these three locations (Stör and Segonzac, 2005). Nevertheless, the distribution of methane- and sulphide-rich sites in the Atlantic is poorly known, particularly in the South Atlantic. As an example, "chemosynthetic mussels" have recently been observed in the Gulf of Cadiz (D. Masson et al., unpublish.). As suggested by Vermeij (2005), amphi-Atlantic molluscs may have originated from brief episodes particularly favorable to transatlantic expansion, acting as potential stepping stones (e.g. relatively warm Arctic Ocean for shallow-water species). However, this author reports that molecular studies for several shallow-water molluscs all pointed to differences between eastern and western populations that imply substantial genetic isolation, in contrast with the deep- chemosynthetic mussels.

The two Bathymodiolus species complexes studied here seem to display the same patterns of dispersal (i.e. identical migration routes) but in different depth ranges. The B. childressi complex indeed seems to occur at two relatively "shallow" depths, ranging between 540 and $2200 \mathrm{~m}$ along the Louisiana slope, between 1000 and $1700 \mathrm{~m}$ on the Barbados prism, and between 1000 and $1260 \mathrm{~m}$ off Mauritania. Conversely, the B. boomerang complex has been recorded from deeper areas between 1700 and $2000 \mathrm{~m}$ on the Barbados prism and the Blake Ridge diapir and more than $3000 \mathrm{~m}$ off Congo and at the Florida Escarpment. Propagules are thus likely to be entrained through different water layers according to their depth range, and it would now be very interesting to study population differentiation within these two different complexes of species to quantify levels of gene flow between and along the American and African margins.

\section{Conclusion}

Based on morphological and molecular analyses, we showed the occurrence of two complexes of amphiAtlantic bathymodiolin mussels (the Bathymodiolus childressi and the Bathymodiolus boomerang complexes) associated with cold seeps. Within the B. boomerang complex, the COI phylogeny suggests that B. heckerae is genetically different from the two others. However, two isolated populations of 
Amazonian and African B. boomerang may exist. We thus propose to provisionally name the Bathymodiolus sp.A from the Gulf of Guinea cold-seep site REGAB Bathymodiolus aff. boomerang until we obtain larger specimens for morphological, especially allometric, comparisons. Similarly, $B$. mauritanicus from Mauritania to Nigeria and Bathymodiolus sp. B (Barbados) could represent a true amphi-Atlantic species.

These complexes of cold-seep species seem to share a similar colonization history across the Atlantic and thus are likely to display recent vicariant events. Although some teleplanic larvae may still be crossing the Atlantic using equatorial jets or shallower currents, the more likely explanation of the maintenance of amphi-Atlantic species is the very recent colonization of these zones together with a very low evolutionary rate of this peculiar fauna.

\section{Acknowledgments}

The ZAIANGO and BIOZAIRE programs were co-funded by TOTAL and Ifremer (P.I.s respectively B. Savoye \& M. Sibuet). This study is supported by national (ANR Biodiversité DEEPOASES), European (MARBEF) and international (Census of Marine Life/ChEss) programmes on marine biodiversity. Exploration and Biogeography of Deep-Water Chemosynthetic Ecosystems on the Atlantic Equatorial Belt region is one of the main topics objectives of ChEss. Several recent bits of data or comments included in the present paper and referred to as personal communications (M. Arhan, D. Desbruyères, C. Young,) were presented at the last ChEss meeting in Barcelona (2006), and we thank their authors for helpful discussions. We particularly thank Paul Tyler and Chris German (P.I.s), Daniel Desbruyères (P.I. for the AEB region) and Eva Ramirez and Maria Baker (project managers). Molecular work has been funded by the programmes DORSALES (AO Evolution and Population Genetics) and GENOMER, the Network of Excellence "Marine Genomics Europe". We are particularly grateful to C.R Fisher, A. Fiala, Z.P. McKiness and C.M. Cavanaugh for providing biological material and T. Comtet for his laboratory help. We thank the chief scientists of the French, American and Japanese oceanographic cruises that 
collected specimens used for this study: A.-M. Alayse, J.-M. Auzende, D. Desbruyères, J.-C. Faugères, F. Gaill, J. Hashimoto, I.R. MacDonald, S. Ohta, H. Ondréas, D. Prieur, M. Sibuet, C.L Van Dover and D. Wiesenberg and also the captains and crew of the oceanographic cruises. We also want to thank R.C. Vrijenhoek and the 3 anonymous referees for their useful comments on early versions of the manuscript. Part of this work was also supported by the NOAA National Undersea Research Program at the University of North Carolina, NSF-EAR-9158113, subcontract L100094 to the Mineral Management Service, and by the Gulf of Mexico Regional OCS Office through contract number 1435-01-96-CT30813.

We are also very indebted to IFREMER/GENAVIR, Woods Hole Oceanographic Institution and Harbor Branch Oceanographic Institution for the use of deep manned submersibles and ROVs, without which this work would not have been possible.

\section{References}

Andersen, A.C., Hourdez, S., Marie, B., Jollivet, D., Lallier, F.H.,Sibuet, M., 2004. Escarpia southwardae sp. nov., a new species of vestimentiferan tubeworm (Annelida, Siboglinidae) from West African cold seeps. Canadian Journal of Zoology 82, 980-999.

Amos, A.F., Gordon, A.I., Schneider, E.D., 1971. Water masses and circulation patterns in the region of the Blake-Bahama Outer Ridge. Deep Sea Research 18, 145-165.

Andrié, C., Rhein, M., Freudenthal, S., Plähn O, 2002. CFC time series in the deep water masses of the western tropical Atlantic, 1990-1999. Deep Sea Research I 49, 281-304.

Arhan, M., Mercier, H., Bourlès, B., Gouriou, Y., 1998. Hydrographic sections across the Atlantic at $7^{\circ} 30 \mathrm{~N}$ and $4^{\circ} 30 \mathrm{~S}$. Deep Sea Research I 45, 829-872.

Bayne, B.L., 1965. Growth and the delay of metamorphosis of the larvae of Mytilus edulis (L.). Ophelia 2, 1-47.

Bazin, E., Glémin, S., Galtier, N., 2006. Population size does not influence mitochondrial genetic diversity in animals. Science 312, 570-572.

Berger, M.S., Young, C.M., 2006. Physiological response of the cold-seep mussel Bathymodiolus childressi to acutely elevated temperature. Marine Biology 149, 1397-1402

Bourlès, B., Andrié, C., Gouriou, Y., Eldin, G., Du Penhoat, Y., Freudenthal, S., Dewitte, B., Gallois, F., Chuchla, R., Baurand, F., Aman, A., Kouadio, G., 2003. The deep currents in the eastern equatorial Atlantic Ocean. Geophysical Research Letters, 30, 5, 8002

Carney, S.L., Formica, M.I., Divatia, H., Nelson, K., Fisher, C.R., Schaeffer, S.W., 2006. Population structure of the mussel "Bathymodiolus" childressi from Gulf of Mexico hydrocarbon seeps. Deep Sea Research I 53, 1061-1072.

Charlou, J.L., Donval, J.P., Fouquet Y., Ondréas, H., Knoery, J., Cochonat, P., Levaché, D., Poirier, Y., Jean-Baptiste, P., Fourre, E., The ZAIROV Leg 2 Scientific Party, 2004. Physical and chemical characterization of gas hydrates and associated methane plumes in the Congo-Angola Basin. Chemical Geology 205, 405-425.

Chevaldonné, P., Jollivet, D., Vangriesheim, A., Desbruyères, D., 1997. Hydrothermal-vent alvinellid polychaete dispersal in the eastern Pacific. 1. Influence of vent site distribution, bottom currents, and biological patterns. Limnology and Oceanography 42, 67-80. 
Chevaldonné, P., Jollivet, D., Desbruyères, D., Lutz, R.A., Vrijenhoek, R.C., 2002. Sister-species of eastern Pacific hydrothermal vent worms (Ampharetidae, Alvinellidae, Vestimentifera) provide new mitochondrial COI clock calibration. Cahiers de Biologie Marine 43, 367-370.

Coates, A.G., Obando, J.A., 1996. The geologic evolution of the Central American Isthmus. In Evolution and environment in tropical America (ed. Jackson JBC, Budd AF, Coates AG), pp 21-56. Chicago: The University of Chicago Press.

Comtet, T., Jollivet, D., Khripounoff, A., Segonzac, M.,Dixon, D.R., 2000. Molecular and morphological identification of settlement-stage vent mussel larvae, Bathymodiolus azoricus (Bivalvia: Mytilidae), preserved in situ at active vent fields on the Mid-Atlantic Ridge. Limnology and Oceanography 45, 1655-1661.

Cordes, E.E., Carney, S.L., Hourdez, S., Carney, R.S., Brooks, J.M., Fisher, C.R., 2007. Cold seeps of the deep Gulf of Mexico: Community structure and biogeographic comparaisons to Atlantic equatorial belt seep communities. Deep-Sea Research I 54, 637-653.

Cosel, R von, 1982. Marine Mollusken der Kapverdischen Inseln. Übersicht mit zoogeographischen Anmerkungen. Courier Forschungsinstitut Senckenberg 52, 35-76.

Cosel, R von, 2002. A new species of bathymodioline mussel (Mollusca, Bivalvia, Mytilidae) from Mauritania (West Africa), with comments on the genus Bahymodiolus Kenk \& Wilson, 1985. Zoosystema 24, 259-271.

Cosel, R.von, Métivier, B.,Hashimoto, J., 1994. Three new species of Bathymodiolus (Bivalvia: Mytilidae) from hydrothermal vents in the Lau basin and the North Fiji basin, Western pacific, and the Snake pit area, Mid-Atlantic Ridge. The Veliger 37, 374-392.

Cosel, R.von, Olu, K., 1998. Gigantism in Mytilidae. A new Bathymodiolus from cold seep areas on the Barbados accretionary Prism. Comptes Rendus de l'Académie des Sciences de Paris, Série II 321, 655-663.

Desbruyères, D., Almeida, A., Biscoito, M., Comtet, T., Khripounoff, A., Le Bris, N., Sarradin, P.M., Segonzac, M., 2000. A review of the distribution of hydrothermal vent communities along the northern Mid-Atlantic Ridge: dispersal vs environmental controls. Hydrobiologia 440, 201-216.

Dixon, D.R., Lowe, D.M., Miller, P.I., Villemin, G.R., Colaço, A., Serrão-Santos, R., Dixon, L.R.J., 2006. Evidence of seasonal reproduction in the Atlantic vent mussel Bathymodiolus azoricus, and apparent link with the timing of photosynthetic primary production. Journal of the Marine Biology Association of the United Kingdom, 86, 1363-1371.

Duperron, S., Nadalig, T., Caprais, J.C., Sibuet, M., Fiala-Médioni, A., Amann, R.,Dubilier, N., 2005. Dual symbiosis in a Bathymodiolus sp mussel from a methane seep on the gabon continental margin (southeast Atlantic): 16S rRNA phylogeny and distribution of the symbionts in gills. Applied and Environmental Microbiology 71, 1694-1700.

Felsenstein J, 1981. PHYLIP: Phylogeny inference package (version 3.2). Cladistics 5, 164-166

Folmer, O., Black, M., Hoeh, W., Lutz, R.,Vrijenhoek, R.C., 1994. DNA primers for amplification of mitochondrial cytochrome $\mathrm{C}$ oxidase subunit I from metazoan invertebrates. Molecular Marine Biology and Biotechnology 3, 294-299.

German, C., Parson, L.M., Heat Scientific Team, 1996. Hydrothermal exploration near the Azores Triple Junction: Tectonic control of venting at slow-spreading ridges? Earth and Planetary Science Letters 138, 93-104.

Gill, F.L., Harding, I.C., Little, C.T.S., Todd, J., 2005. Cenozoic cold seep communities and associated carbonates from the southern Caribbean region. Palaeogeography, Palaeoclimatology, Palaeoecology 227, 191-209.

Gustafson, R.G., Turner, R.D., Lutz, R.A.,Vrijenhoek, R.C., 1998. A new genus and five new species of mussels (Bivalvia, Mytilidae) from deep-sea sulfide/hydrocarbon seeps in the Gulf of Mexico. Malacologia 40, 63-112. 
Haddad, G.A., Droxler, A.W., 1996. Metastable CaCo3 dissolution at intermediate water depths of the carribean and western North Atlantic: Implications for intermediate water circulation during the past 200,000 years. Paleoceanography 11, 701-716.

Hasegawa, M., Kishino, H., Yano, K., 1985. Dating of the human-ape splitting by a molecular clock of mitochondrial DNA. Journal of Molecular Evolution 22, 160-174.

Hecker, B., 1985. Fauna from a cold sulfur-seep in the gulf of Mexico: comparison with hydrothermal vent communities and evolutionary implications. Bulletin of the Biological Society of Washington 6, 465-473.

Heezen, B.C., Gerard, R.D., Tharp, M., 1964. The Vema Fracture Zone in the equatorial Atlantic. Journal of Geophysical Research 69, 733-750.

Jollivet, D., 1996. Genetic diversity and biodiversity at deep-sea hydrothermal vents: an overview. Biodiversity and Conservation 5, 1619-1653.

Jollivet, D. Comtet, T., Chevaldonné, P., Hourdez, S., Desbruyères, D., Dixon, D., 1998. Unexpected relationship between dispersal strategies and speciation within the association Bathymodiolus (Bivalvia) Branchipolynoe (Polychaeta) inferred from the rDNA neutral ITS2 marker. Cahiers de Biologie Marine 39, 359-362.

Jollivet, D., Faugères, J.C., Griboulard, R., Desbruyères, D., Blanc, G., 1990. Composition and spatial organization of a cold seep community on the South Barbados accretionnary prism: tectonic, geochemical and sedimentary context. Progress in Oceanography 24, 25-46.

Jones, W.J., Won, Y.J., Maas, P.A.Y., Smith, P.J., Lutz, R.A., Vrijenhoek, R.C., 2006. Evolution of habitat use by deep-sea mussels. Marine Biology 148, 841-851.

Jones, W.J., Vrijenhoek, R.C., 2006. Evolutionary relationships within the "Bathymodiolus" childressi group. Cahiers de Biologie Marine 47, 403-407.

Kimura, M., 1980. A simple method for estimating evolutionary rates of base substitution through comparative studies of nucleotide sequences. Journal of Molecular Evolution 16, 111-120.

Knowlton, N., Weigt, L.A., 1998. New dates and new rates for divergence across the Isthmus of Panama. Proceedings of the Royal Society of London B 265, 2257-2263.

Komai, T., Segonzac, M., 2005. A revision of the genus Alvinocaris Williams and Chace (Crustacea: Decapoda: Caridea: Alvinocaridea), with descriptions of a new genus and a new species of Alvinocaris. Journal of Natural History 39, 1111-1175.

Little, C.T.S., Vrijenhoek, R.C., 2003. Are hydrothermal vent animals living fossils? Trends in Ecology and Evolution 18:582.

Macpherson, E., Segonzac, M., 2005. Species of the genus Munidopsis (Crustacea, Decapoda, Galatheidae) from the deep Atlantic Ocean, including cold-seep and hydrothermal vent areas. Zootaxa 1095:1-60.

Marie, D., Zhu, F., Balagué, V., Ras, J., Vaulot, D., 2006. Eukaryotic picoplankton communities of the Mediterranean Sea in summer assessed by molecular approaches (DGGE, TTGE, QPCR). FEMS Microbiology Ecology 55, 403-415.

Marsh, A.G., Mullineaux, L.S., Young, C.M., Manahan, D.T., 2001. Larval dispersal potential of the tubeworm Riftia pachyptila at deep-sea hydrothermal vents. Nature 411, 77-80.

McMullin, E.R., Hourdez, S., Schaeffer, S.W., Fisher, C.R., 2003. Phylogeny and Biogeography of Deep Sea Vestimentiferan Tubeworms and Their Bacterial Symbionts. Symbiosis 34, 1-41.

Mercier, H., Speer, K.G., 1998. Transport of bottom water in the Romanche Fracture Zone and the Chain Fracture Zone. Journal of Physical Oceanography 28, 779-790.

Metaxas, A., Giffin, B., 2004. Dense beds of the ophiuroid Ophiacantha abyssicola on the continental slope off Nova Scotia, Canada. Deep Sea Research I 51, 1307-1317.

Miyazaki, J.I., Shintaku, M., Kyuno, A., Fujiwara, Y., Hashimoto, J., Iwasaki, H., 2004. Phylogenetic relationships of deep-sea mussels of the genus Bathymodiolus (Bivalvia: Mytilidae). Marine Biology 144, 527-535. 
Mullineaux, L.S., 1995. Dispersal mechanisms of deep-sea hydrothermal vent fauna. In: Humphris, S. E., Zierenberg, R. A., Mullineaux, L. S.,Thomson, R. E. (eds) Seafloor hydrothermal systems, Vol 91. American Geophysical Union, Washington DC, p 408-424

Mullineaux, L.S., Fisher, C.R., Peterson, C.H.,Schaeffer, S.W., 2000. Tubeworm succession at hydrothermal vents: use of biogenic cues to reduce habitat selection error? Oecologia 123, 275284.

Mullineaux, L.S., Mills, S.W., Sweetman, A.K., Beaudreau, A.H., Metaxas, A.,Hunt, H.L., 2005. Vertical, lateral and temporal structure in larval distributions at hydrothermal vents. Marine Ecology Progress Series 293, 1-16.

Olu-Le Roy, K., Caprais, J.C., Nadalig, T., Fifis, A., Fabri, M.C., Galéron, J., Khripounoff, A., Budzinski, H., Ondréas, H., Sibuet, M., 2007. Cold seep community on a giant pockmark off West Africa: spatial patterns and environmental control. Marine Ecology, An evolutionary perspective, Special topics volume: Ecology and evolution of vent, seep and whale fall organisms. 28, 115-130.

Olu-Le Roy, K., Sibuet, M., Fiala-Médioni, A., Gofas, S., Salas, C., Mariotti, A., Foucher, J.P.,Woodside, J., 2004. Cold seep communities in the deep eastern Mediterranean Sea: composition, symbiosis and spatial distribution on mud volcanoes. Deep-Sea Research I 51, 1915-1936.

Olu, K., Sibuet, M., Harmegnies, F., Foucher, J.-P.,Fiala-Medioni, A., 1996. Spatial distribution of diverse cold seep communities living on various diapiric structures of the southern Barbados prism. Progress in Oceanography 38, 347-376.

O’Mullan, G.D., Maas, P.A.Y., Lutz, R.A., Vrijenhoek, R.C., 2001. A hybrid zone between hydrothermal vent mussels (Bivalvia: Mytilidae) from the Mid-Atlantic Ridge. Molecular Ecology 10, 28192831.

Ondréas, H., Olu, K., Fouquet, Y., Charlou, J., Gay, A., Dennielou, B., Donval, J., Fifis, A., Nadalig, T., Cochonat, P., Cauquil, E., Bourillet, J., Moigne, M.,Sibuet, M., 2005. ROV study of a giant pockmark on the Gabon continental margin. Geo-Marine Letters 25, 281.

Page, R.D.M., 1996. TreeView: an application to display phylogenetic trees on personal computers. Computer Applications in the Biosciences 12, 357-358

Pawson, D.L., 2004. Ovalidota milleri, a new genus and species of bathyal sea cucumber from the Caribbean Sea (Echinodermata: Holothuroidea: Apodida). Zootaxa 561, 1-6.

Posada, D., Crandall, K.A., 2001. Selecting the best-fit model of nucleotide substitution. Systematic Biology 50, 580-601.

Rambaut, A., 1996. Se-Al. A sequence alignment editor, version 1.0 alpha 1. Distributed by the author. Department of Zoology, University of Oxford, Oxford.

Richardson, P.L., Fratantoni, D.M., 1999. Float trajectories in the deep western boundary current and deep equatorial jets of the tropical Atlantic. Deep-Sea Research II 46, 305-333.

Ross, M.I., Scotese, C.R., 1988. A hierarchical tectonic model of the Gulf of Mexico and Caribbean region. Tectonophysics 155, 139-168.

Roth, J.M., Droxler, A.W., Kameo, K., 2000. The Caribbean carbonate crash at the middle to late Miocene transition: linkage to the establishment of the modern global ocean conveyor. Proceeding of the Ocean Drilling Program, Scientific Results: College Station, TX (ODP) 165, 249-273.

Schlötterer, C., Hauser, M.T., Von Haeseler, A., Tautz, D., 1994. Comparative evolutionary analysis of rDNA IST regions in Drosophila. Molecular Biology and Evolution 11, 513-522.

Schmid, C., Bourlès, B., Gouriou, Y., 2005. Impact of the equatorial deep jets on estimates of zonal transports in the Atlantic. Deep-Sea Research II 52, 409-428.

Shank, T.M., Fornari, D.J., Von Damm, K.L., Lilley, M.D., Haymon, R.M., Lutz, R.A., 1998. Temporal and spatial patterns of biological community development at nascent deep-sea hydrothermal vent (950'N, East Pacific Rise). Deep-Sea Research II 45, 465-515. 
Stöhr, S., Segonzac, M., 2005. Deep-sea ophiuroids (Echinodermata) from reducing and non-reducing environments in the North Atlantic Ocean. Journal of the Marine Biological Assocation of the United Kingdom 85, 383-402.

Swofford, D.L., 2002. PAUP*. Phylogenetic Analysis Using Parsimony (*and other methods). Version 4. Sinauer Associates, Sunderland, MA.

Stephens, J.C., Marshall, D.P., 2000. Dynamical pathways of Antarctic bottom water in the Atlantic. Journal of Physical Oceanography 30, 622-640.

Thompson, J.D., Gibson, T.J., Plewniak, F., Jeanmougin, F., Higgins, D.G., 1997. The CLUSTAL_X windows interface: flexible strategies for multiple sequence alignment aided by quality analysis tools. Nucleic Acids Research, 25: 4876-4882

Tunnicliffe, V., Embley, R.W., Holden, J.F., Butterfield, D.A., Massoth, G.J., Juniper, S.K., 1997. Biological colonization of new hydrothermal vents following an eruption on Juan de Fuca Ridge. Deep-Sea Research I 44, 1627-1644.

Tunnicliffe, V., McArthur, A.G., McHugh, D., 1998. A biogeographical perspective of the deep-sea hydrothermal vent fauna. Advances in Marine Biology 34, 352-442.

Tyler, P., Dolan, J., Arellano, S., Brooke, S., Baker, M., Young, C., 2005. Gametogenic periodicity in the chemosynthetic mussel genus Bathymodiolus childressi. Third International Symposium on Hydrothermal Vent and Seep Biology, Scripps Institution of Oceanography, La Jolla (USA), September 12-16, 2005, p 142.

Van Dover, C., Aharon, P., Bernhard, J.M., Caylor, E., Doerries, M., Flickinger, W., Gilhooly, W., Goffredi, S.K., Knick, K., Macko, S.A., Rapoport, S., Raulfs, E.C., Ruppel, C., Salerno, J., Seitz, R.D., Sen Gupta, B.K., Shank, T., Turneipseed, M.,Vrijenhoek, R.C., 2003. Blake Ridge methane seep: characterization of a soft-sediment, chemosynthetically based ecosystem. Deep-Sea Research I 50, 281-300.

Van Dover, C.L., German, C.R., Speer, K.G., Parson, L.M., Vrijenhoek, R.C., 2002. Evolution and biogeography of deep-sea vent and seep invertebrates. Science 295, 1253-1257.

Van Gaest, A.L., Young, C.M., 2005. Development and larval ecology of the cold seep gastropod Bathynerita naticoidea Third International Symposium on Hydrothermal Vent and Seep Biology, Scripps Institution of Oceanography, La Jolla (USA), September12-16, 2005 , p 53.

Vermeij, G.J., 2005. From Europe to America: Pliocene to Recent trans-Atlantic expansion of cold-water North Atlantic molluscs. Proceedings of the Royal Society of London, B 272:2545-2550.

Vrijenhoek, R.C., 1997. Gene flow and genetic diversity in naturally fragmented metapopulations of deep-sea hydrothermal vent animals. Heredity 88, 285-293.

Weiberg, R.H., Hockman, J.H., Tang, T.Y., Weingartner, T.J., 1987. Velocity and temperature observations during the seasonal response of the Equatorial Atlantic Experiment at $0^{\circ}, 28^{\circ} \mathrm{W}$. Geophysical Research 92, 5061-5075.

Won, Y.J., Maas, P.A.Y., Van Dover, C.,Vrijenhoek, R.C., 2002. Habitat reversal in vent and seep mussels: Bathymodiolus heckerae, derived from vent ancestors. Cahiers de Biologie Marine 43, 387-390.

Won, Y., Young, C.R., Lutz, R.A., Vrijenhoek, R.C., 2003. Dispersal barriers and isolation among deepsea mussel populations (Mytilidae: Bathymodiolus) from eastern Pacific hydrothermal vents. Molecular Ecology 12, 169-184. 


\section{Figure caption}

Table 1: Specimen collection sites and GenBank accession numbers for Bathymodiolinae studied in this paper or included in phylogenetic analyses.

Figure 1: Areas of the Atlantic equatorial belt selected by the Census of Marine Life/ChEss program (from D. Desbruyères, available on the ChEss website, http://www.soc.soton.ac.uk/chess/equatorial_belt.html). The bathymodiolins included in this paper correspond to five encircled areas, which are, north to south and west to east, the northern Gulf of Mexico, the Florida Escarpment, the Barbados Accretionary Prism, the Banc d'Arguin off Mauritania, and the Gulf of Guinea.

Figure 2: a. Bathymodiolus sp. A from off Congo. Top: Exterior of left valve, BIOZAIRE 2 PL 147-10, REGAB, 5 $47.78^{\prime} \mathrm{S}, 9^{\circ} 42.65^{\prime} \mathrm{E}, 3151-3159 \mathrm{~m}$. Shell length $166.8 \mathrm{~mm}$. Bottom: Exterior of right and left valve, interior of right valve, BIOZAIRE 2 PL 146-9, REGAB 547.82'S, 942.73'E, 3160-3158 m. Shell length $166.5 \mathrm{~mm}$. b. Half-schematic drawing of the interior of right valve of Bathymodiolus sp. A from off Congo. Foot-byssus retractor muscle complex and its position in the shell. BIOZAIRE 2 PL 146-9, REGAB, 547.82'S, 942.73'E, 3160-3158 m. Shell length $166.5 \mathrm{~mm}$, scale $10 \mathrm{~mm}$.

Figure 3: Top: Bathymodiolus boomerang Cosel \& Olu, 1998, Holotype MNHN, exterior and interior of left valve, Barbados Accretionary Prism, DIAPISUB PL 04, Orenoque A site, $10^{\circ} 19.65 \mathrm{~N}-58^{\circ} 53.5 \mathrm{~W}$, 1690m . Shell length 340.0 mm. Bottom: Juveniles Bathymodiolus boomerang Cosel \& Olu, 1998, exterior of left and interior of right valves, Barbados Accretionary Prism, DIAPISUB, PL DS 10 $\left(10^{\circ} 19.95^{\prime} \mathrm{N}-58^{\circ} 37.30^{\prime} \mathrm{W}, 1950 \mathrm{~m}\right)$. Shell length $115.1 \mathrm{~mm}$. b. Half-schematic drawing of the interior of the right valve of Bathymodiolus boomerang showing the foot-byssus retractor muscle complex and its position in the shell. Juvenile specimen. Barbados Accretionary Prism, DIAPISUB, PL DS 10, Orémoque B, $1950 \mathrm{~m}$. Scale: $10 \mathrm{~mm}$.

Figure 4: Bathymodiolus heckerae Gustafson, Turner, Lutz \& Vrijenhoek, 1998, Top: Paratype 2542-13 MNHN, exterior and interior of right valve, ALVIN dive $\mathrm{N}^{\circ} 2542$, West Florida Escarpment, $26^{\circ} 01.8^{\prime} \mathrm{N}$, 8454.6'W, $3314 \mathrm{~m}$. Shell length $164.1 \mathrm{~mm}$ Bottom: Paratype 2196-59 MNHN, interior and exterior of

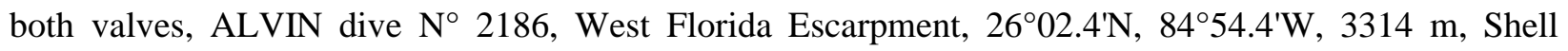
length $84.6 \mathrm{~mm}$ 
Figure 5: a. Bathymodiolus sp. B (Barbados). Upper row and middle: exterior and interior of right valve, dorsal view, Barbados accretionary prism, DIAPISUB, PL DS 05 Orénoque A $\left(10^{\circ} 19.65 \mathrm{~N}-58^{\circ} 53.5 \mathrm{~W}\right.$, $1690 \mathrm{~m})$. Shell length $119.0 \mathrm{~mm}$. Lower row: exterior of left valve, interior of right valve, Barbados Accretionary Prism, DIAPISUB, PL DS 05 Orénoque A. Shell length 80.9 mm. b. Bathymodiolus sp. B. Upper row and middle: exterior and interior of right valve, dorsal view, Barbados Accretionary Prism, DIAPISUB PL DS 15/16 El Pilar (11 $\left.{ }^{\circ} 14 \mathrm{~N}-59^{\circ} 22 \mathrm{~W}, 1060 \mathrm{~m}\right)$. Two specimens of shell length $99.5 \mathrm{~mm}$ and $124.9 \mathrm{~mm}$. Note the broad shells, which are thick and heavy.

Figure 6: Half-schematic drawings of the interior of right valves of Bathymodiolus sp. B. a. Barbados Accretionary Prism, Orénoque A site. shell length $80.5 \mathrm{~mm}$. b. Barbados Accretionary Prism, El Pilar site, foot-byssus retractor muscle complex and its position in the shell. Shell length $99.5 \mathrm{~mm}$. Scale: 10 $\mathrm{mm}$.

Figure 7: Length-height ratio (1/h) versus shell lengths of Bathymodiolus sp. B specimens from Orenoque and El Pilar sites on the Barbados Accretionary Prism ( $\mathrm{n}=51)$.

Figure 8: a. Bathymodiolus mauritanicus Cosel, 2002, Holotype MNHN, interior and exterior of right valve, off Banc d'Arguin, Mauritania, $1200 \mathrm{~m}$, Shell length $98.1 \mathrm{~mm}$. b. Bathymodiolus childressi Gustafson, Turner, Lutz \& Vrijenhoek, 1998, paratype 3129-52 MNHN, exterior and interior of right valve. Johnson Sea-Link 1, dive 3129, Bush Hill hydrocarbon seep, 2746.9'N, 91³0.4'W, $566 \mathrm{~m}$. Shell length 83.6 mm. c.: Bathymodiolus childressi Gustafson, Turner, Lutz \& Vrijenhoek, 1998, paratype 2211-59 MNHN/ exterior of both valves, interior of right valve, Alaminos Canyon, $26^{\circ} 21.3^{\prime} \mathrm{N}$, $94^{\circ} 29.7^{\prime} \mathrm{W}, 2222 \mathrm{~m}$. Shell length $61.7 \mathrm{~mm}$

Figure 9: NJ tree based on the COI mitochondrial sequences (380 bp). with bootstrap values obtained from 10000 resamplings of the dataset. Figures in brackets correspond to bootstrap values obtained with the Maximum Likelihood (ML) method with 100 replicates. The trees have been oriented using the midpoint rooting method using clades previously proposed by Jones et al. (2006) but could also be viewed as unrooted trees. Bmaurit=B. mauritanicus from off Côte d'Ivoire; Bniger6 \& 7: B. cf. mauritanicus from off Nigeria; BathDSxx and BathPIL: B. sp.B from Barbados prism (DS: Orenoque site; PIL=Pilar site); Bchild=B. childressi from the Gulf of Mexico $(\mathrm{GoM})$; Bbrook=B. brooksi $(\mathrm{GoM})$; Bputeo=B. puteoserpentis (MAR); Bazori=B. azoricus (MAR); BathZaire=B. sp. A from REGAB site (Congo seeps); Bniger1\&5=B. sp. Niger A from off Nigeria; Bboo=B. boomerang from Barbados; 
Bhecker=B. heckerae from Florida Escarpment; Bthermo=B. thermophilus $(\mathrm{EPR})$; Bbrevior=B. brevior from Lau Basin/Mariana Trough.

Figure 10: K2P-frequency histogram between specimens collected within the B. childressi complex of species with (black circles) and without (white circles) the 6 B. childressi mtCOI sequences.

Figure 11: K2P-frequency histogram between specimens collected within the B. boomerang complex of species with (black circles) and without (white circles) the 2 B. heckerae mtCOI sequences.

Figure 12: Maximum Parsimony (MP) tree based on the rDNA spacer ITS 2 (472bp) with bootstrap values (in brackets) obtained from 100 replicates. Figures without brackets correspond to bootstrap values obtained with the Neighbor-Joining (NJ) method with 10000 resamplings of the dataset. The tree is oriented using the midpoint rooting method using clades previously proposed by Jones et al. (2006) but could also be viewed as unrooted trees. Bbar: B. sp.B from Barbados prism (DS: Orenoque site; PIL=Pilar site); Bchild=B. childressi from the Gulf of Mexico $(\mathrm{GoM})$; Bboo=B. boomerang from Barbados; Bzaire=B. sp. A from REGAB site (Congo seeps); Bheckeaer=B. heckerae from GoM. 


\begin{tabular}{|c|c|c|c|c|c|c|}
\hline Species & $\begin{array}{l}\text { A bbreviation } \\
\text { in trees }\end{array}$ & Location & L at/Long & Depth & A ccession N umber & Reference \\
\hline Bathymodiolus sp.A & $\begin{array}{l}\text { BathZaire } \\
\text { (COI) } \\
\text { Bzaire (ITS) }\end{array}$ & $\begin{array}{l}\text { Congo-Angola margin, REGAB } \\
\text { site }\end{array}$ & $5^{\circ} 47.8^{\prime} \mathrm{S}, 9^{\circ} 42.7^{\prime} \mathrm{E}$ & $3170 m$ & $\begin{array}{l}\text { COI: DQ513442-43-45- } \\
\text { 47-50-51 } \\
\text { ITS2: DQ 513493 to -497 }\end{array}$ & This study \\
\hline B. boomerang & $\begin{array}{l}\text { Bboo } \\
\text { (COI/ITS2) }\end{array}$ & B arbados prism Orenoque $B$ site & $10^{\circ} 19.9^{\prime} \mathrm{N}, 58^{\circ} 37.3^{\prime} \mathrm{W}$ & $1950 \mathrm{~m}$ & $\begin{array}{l}\text { COI: Q513444-46-48-49 } \\
\text { ITS2 : Q513486 }\end{array}$ & This study \\
\hline B. heckerae & Bhecke & Florida Escarpment & $\begin{array}{l}26^{\circ} 01.8^{\prime} \mathrm{N}, 84^{\circ} 54.9^{\prime} \mathrm{W} \\
26^{\circ} 01.8^{\prime} \mathrm{N}, 84^{\circ} 54.9^{\prime} \mathrm{W} \\
26^{\circ} 01.8^{\prime} \mathrm{N}, 84^{\circ} 54.9^{\prime} \mathrm{W}\end{array}$ & $\begin{array}{l}3290 \mathrm{~m} \\
3290 \mathrm{~m} \\
3290 \mathrm{~m}\end{array}$ & $\begin{array}{l}\text { A Y 649794, AY 649793 } \\
\text { COI:D Q513441 } \\
\text { ITS2 : DQ 513490-492 }\end{array}$ & $\begin{array}{l}\text { Jones et al. } 2006 \\
\text { This study } \\
\text { This study }\end{array}$ \\
\hline Bathymodiolus sp.B & $\begin{array}{l}\text { BathDS } \\
\text { BathPIL }\end{array}$ & $\begin{array}{l}\text { Barbados prism Orenoque A site, } \\
\text { B arbados prism El Pilar site }\end{array}$ & $\begin{array}{l}10^{\circ} 19.6^{\prime} \mathrm{N}, 58^{\circ} 53.5^{\prime} \mathrm{W} \\
11^{\circ} 14^{\prime} \mathrm{N}, 59^{\circ} 22^{\prime} \mathrm{W}\end{array}$ & $\begin{array}{l}1690 m \\
1200 m\end{array}$ & $\begin{array}{l}\text { COI:DQ513425 to } 440 \\
\text { ITS2: DQ513484-85 }\end{array}$ & This study \\
\hline B. childressi (ITS) & $\begin{array}{l}\text { Bchilda } \\
\text { Bchildb }\end{array}$ & $\begin{array}{l}\text { L ouisiana slope,B rinePool ( } 2 \text { ind) } \\
\text { L ouisiana slope,A laminos canyon }\end{array}$ & $\begin{array}{l}27^{\circ} 43.4^{\prime} \mathrm{N}, 91^{\circ} 16.3^{\prime} \mathrm{W} \\
26^{\circ} 21.3^{\prime} \mathrm{W}, 94^{\circ} 29.8^{\prime} \mathrm{N}\end{array}$ & $\begin{array}{l}650 \mathrm{~m} \\
2200 \mathrm{~m}\end{array}$ & $\begin{array}{l}\text { ITS2: DQ513475- } 478 \text { to } \\
-483\end{array}$ & This study \\
\hline B. childressi (COI) & $\begin{array}{l}\text { BchildM S1 } \\
\text { BchildG C } 1 \\
\text { BchildB H 1 } \\
\text { BchildA L 1 }\end{array}$ & $\begin{array}{l}\text { L ouisiana slope, A laminos canyon } \\
\text { L ouisiana slope, GC } 929 \text { site } \\
\text { L ouisiana slope, Bush Hill } \\
\text { A laminos canyon }\end{array}$ & \begin{tabular}{|l|}
$28^{\circ} 01^{\prime} \mathrm{N}, 89^{\circ} 43^{\prime} \mathrm{W}$ \\
$27^{\circ} 46^{\prime} \mathrm{N}, 91.07^{\prime} \mathrm{W}$ \\
$27^{\circ} 47^{\prime} \mathrm{N}, 91^{\circ} 30.5^{\prime} \mathrm{W}$ \\
$26^{\circ} 21^{\prime} \mathrm{N}-94^{\circ} 29^{\prime} \mathrm{W}$
\end{tabular} & $\begin{array}{l}2222 \mathrm{~m} \\
642 \mathrm{~m} \\
540 \mathrm{~m} \\
2222 \mathrm{~m}\end{array}$ & $\begin{array}{l}\text { AY } 649800 \\
\text { DQ177879-884 } \\
\text { DQ177879-884 } \\
\text { EF 051241-EF051246 }\end{array}$ & $\begin{array}{l}\text { Jones et al. } 2006 \\
\text { Carney et al. } 2006 \\
\text { Carney et al. } 2006 \\
\text { Cordes et al. } 2007\end{array}$ \\
\hline B. mauritanicus & B. maurit & South of the Côte d'Ivoire & $0^{\circ} 53^{\prime} \mathrm{N}, 5^{\circ} 28^{\prime} \mathrm{W}$ & $1000-1267 \mathrm{~m}$ & AY 649801 & J ones et al. 2005 \\
\hline B. sp. NigerA & BNiger1\& 5 & Nigerian slope & $4^{\circ} 59^{\prime} \mathrm{N}, 4^{\circ} 08^{\prime} \mathrm{E}$ & $1000-1700 \mathrm{~m}$ & EF 051242-243 & Cordes et al. 2007 \\
\hline $\begin{array}{l}\text { B. sp. NigerB } \\
=\text { B. cf mauritanicus }\end{array}$ & BNiger6\& 7 & Nigerian slope & $4^{\circ} 59^{\prime} \mathrm{N}, 4^{\circ} 08^{\prime} \mathrm{E}$ & $1000-1700 m$ & EF 051241 & Cordes et al. 2007 \\
\hline B. brooksi & Bbrook & Alaminos Canyon & $26^{\circ} 21.3^{\prime} \mathrm{N}, 94^{\circ} 29.7^{\prime} \mathrm{W}$ & $2222 \mathrm{~m}$ & $\begin{array}{l}\text { ITS:DQ } 513476 \text { and }-477 \\
\text { COI :AY } 649797-798\end{array}$ & $\begin{array}{l}\text { This study } \\
\text { J ones et al. } 2006\end{array}$ \\
\hline B. thermophilus & Bthermo & $\begin{array}{l}\text { EPR } 9^{\circ} 50^{\prime} \mathrm{N} \text { Riftia field } \\
18^{\circ} \mathrm{S} / \mathrm{EPR} \text { A nimal farm }\end{array}$ & $\begin{array}{l}9^{\circ} 50.96^{\prime} \mathrm{N}, 104^{\circ} 17.7 \mathrm{~W} \\
18^{\circ} 35^{\prime} \mathrm{S}, 13^{\circ} 25^{\prime} \mathrm{W}\end{array}$ & $\begin{array}{l}2515 m \\
2673 m\end{array}$ & $\begin{array}{l}\text { ITS2: DQ513452 and } 454 \\
\text { COI:AF456282 }\end{array}$ & $\begin{array}{l}\text { This study } \\
\text { W on et al. } 2003\end{array}$ \\
\hline B. azoricus & Bazori & $\begin{array}{l}\text { MAR, M enez Gwen site } \\
\text { MAR, L ucky Strike site }\end{array}$ & $\begin{array}{l}37^{\circ} 50.6^{\prime} \mathrm{N}, 31^{\circ} 313^{\prime} \mathrm{W} \\
37^{\circ} 17.6^{\prime} \mathrm{N}, 32^{\circ} 1696^{\prime} \mathrm{W}\end{array}$ & $824 m$ & $\begin{array}{l}\text { ITS2: DQ513464 and } 467 \\
\text { COI: AY } 649795\end{array}$ & $\begin{array}{l}\text { This study } \\
\text { J ones et al. } 2006\end{array}$ \\
\hline B. puteoserpentis & Bputeo & MAR, L ogatchev site & $14^{\circ} 45.2^{\prime} \mathrm{N}, 44^{\circ} 58.76^{\prime} \mathrm{W}$ & $3065 \mathrm{~m}$ & $\begin{array}{l}\text { ITS2: DQ513458 } \\
\text { COI: AY } 649796\end{array}$ & $\begin{array}{l}\text { This study } \\
\text { J ones et al. } 2006\end{array}$ \\
\hline B. brevior & Bbrevior & $\begin{array}{l}\text { North Fiji B asin, White Lady } \\
\text { L au B ack A rc basin } \\
\text { M ariana Through }\end{array}$ & $16^{\circ} 59.4^{\prime} S, 173^{\circ} 549^{\prime} E$ & $1990 \mathrm{~m}$ & $\begin{array}{l}\text { ITS2: DQ513470 } \\
\text { COI : A Y } 275544 \\
\text { COI: AY } 649799\end{array}$ & $\begin{array}{l}\text { This study } \\
\text { Smith et al. } 2005 \\
\text { J ones et al. } 2006\end{array}$ \\
\hline B. elongatus & Belongatus & North Fiji B asin, Sunset & $18^{\circ} 49^{\prime} \mathrm{S}, 173^{\circ} 29^{\prime} \mathrm{E}$ & $2720 m$ & ITS2: DQ513471 & This study \\
\hline
\end{tabular}


Figure 1
Click here to download high resolution image

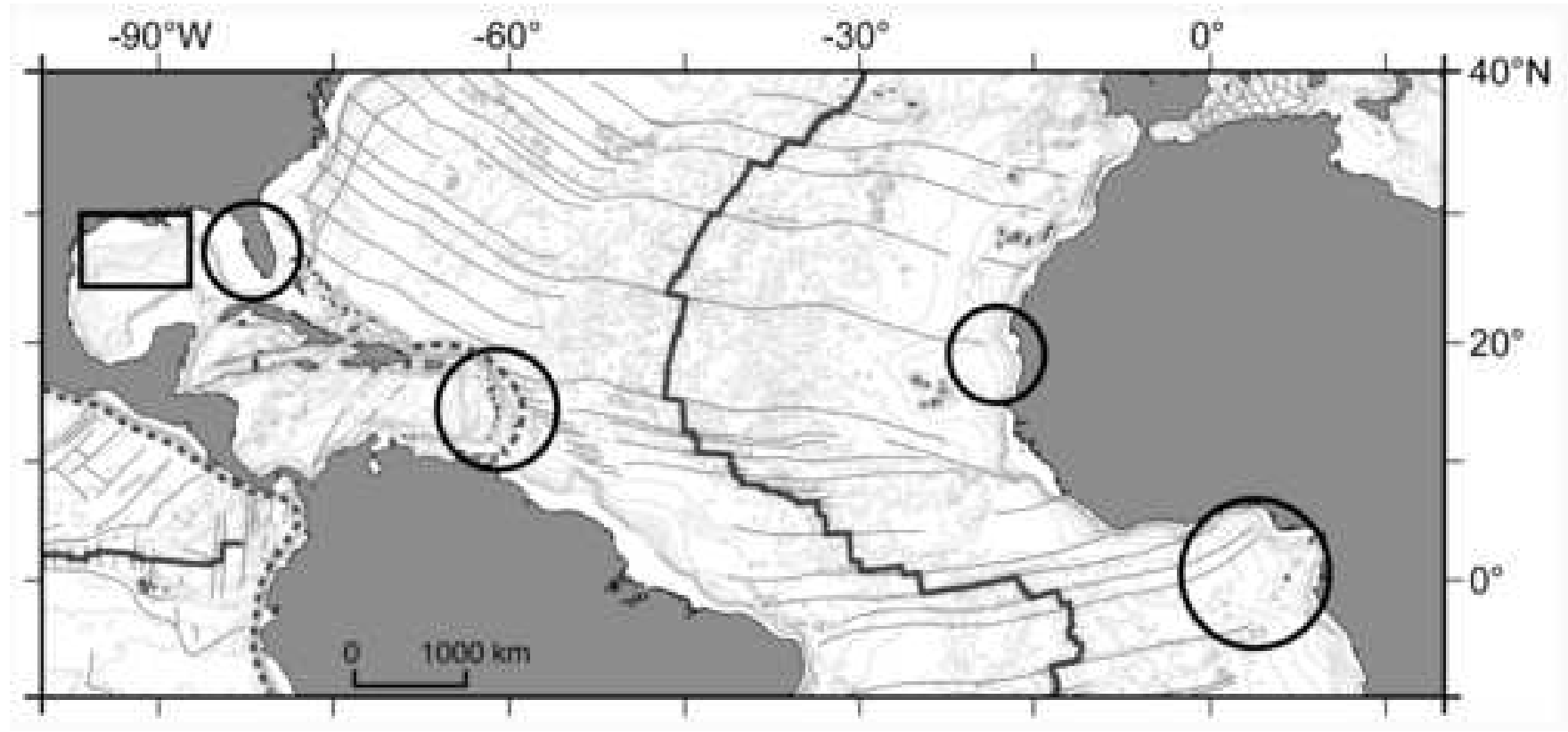

ge

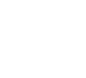

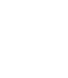

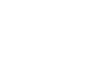

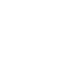

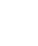

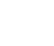

.

.

.

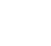

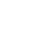

.

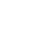
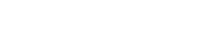

-

$\sqrt{20}+2$
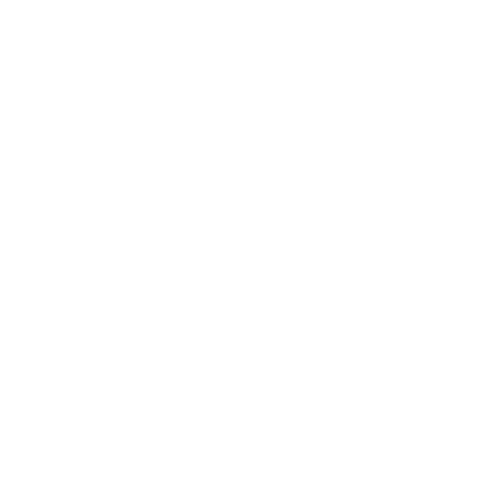
Click here to download high resolution image
Click

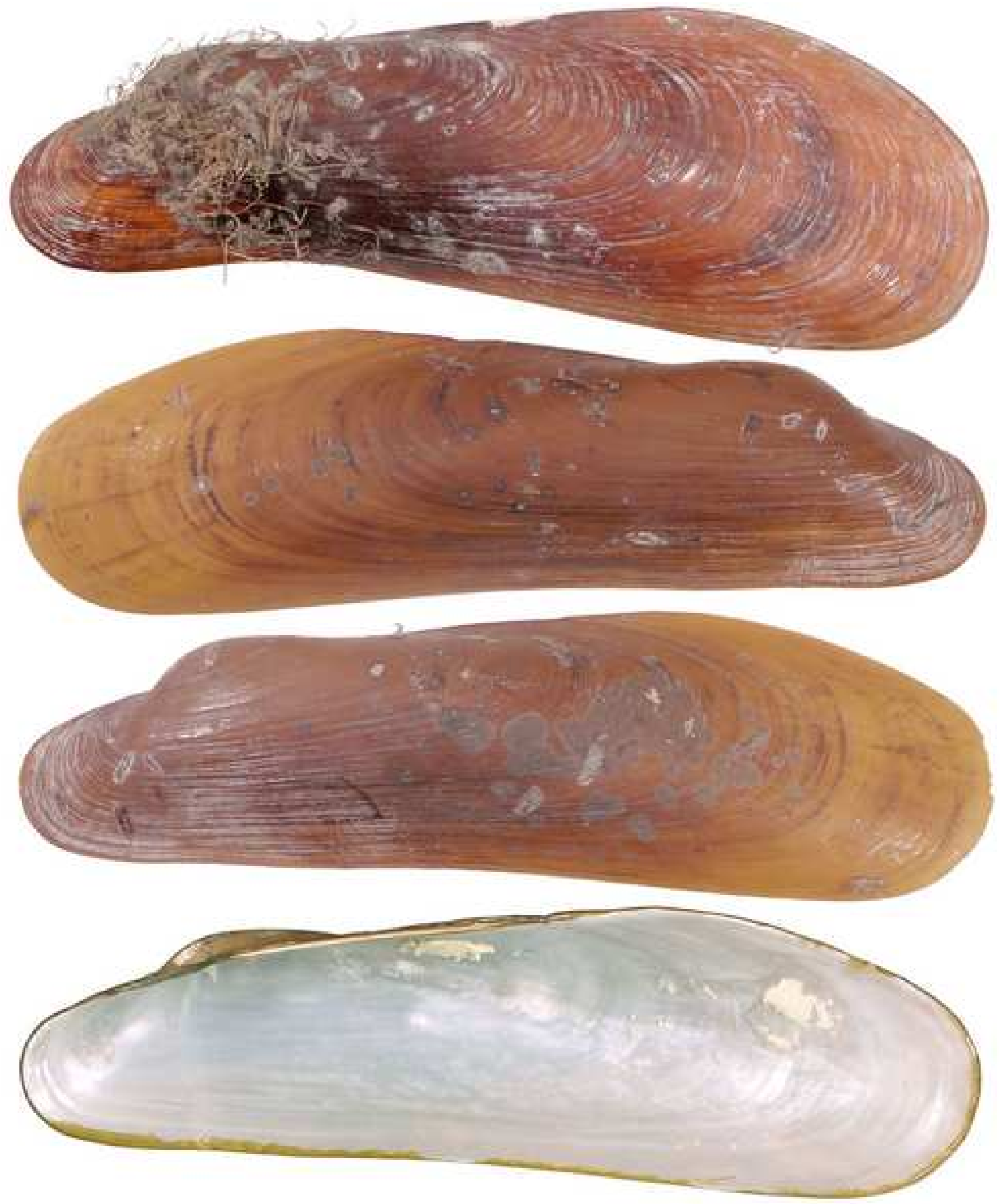


Figure2b
Click here to download high resolution image

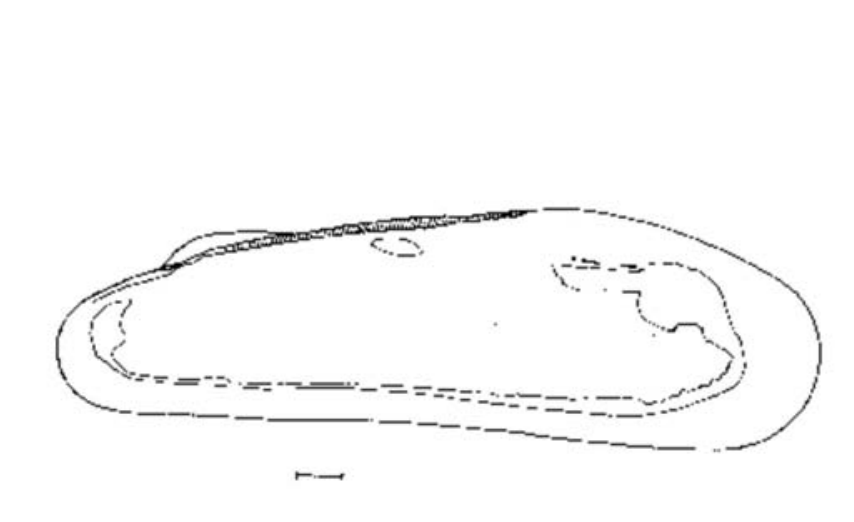

\begin{abstract}
Click here to download high resolution image
\end{abstract}

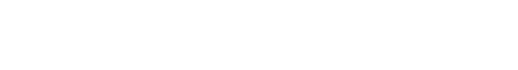

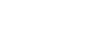

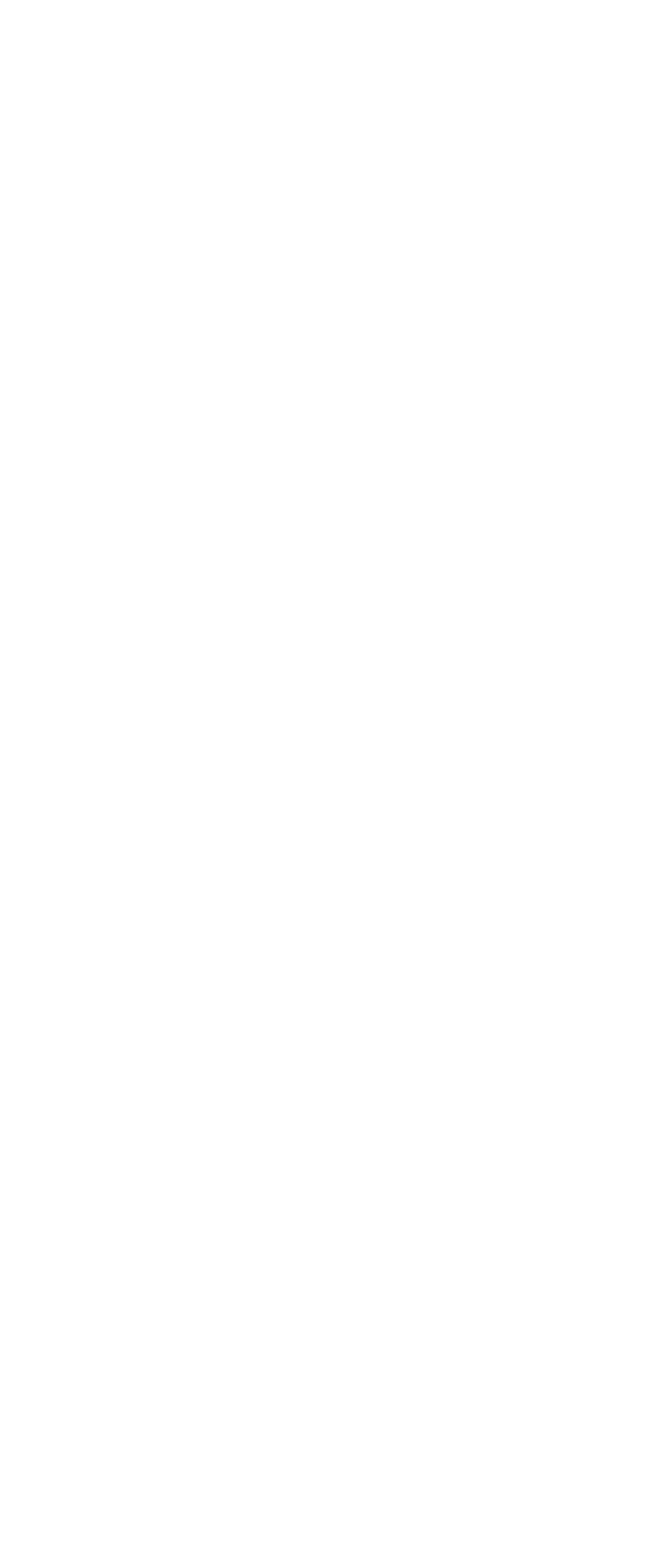


Click here to download high resolution image
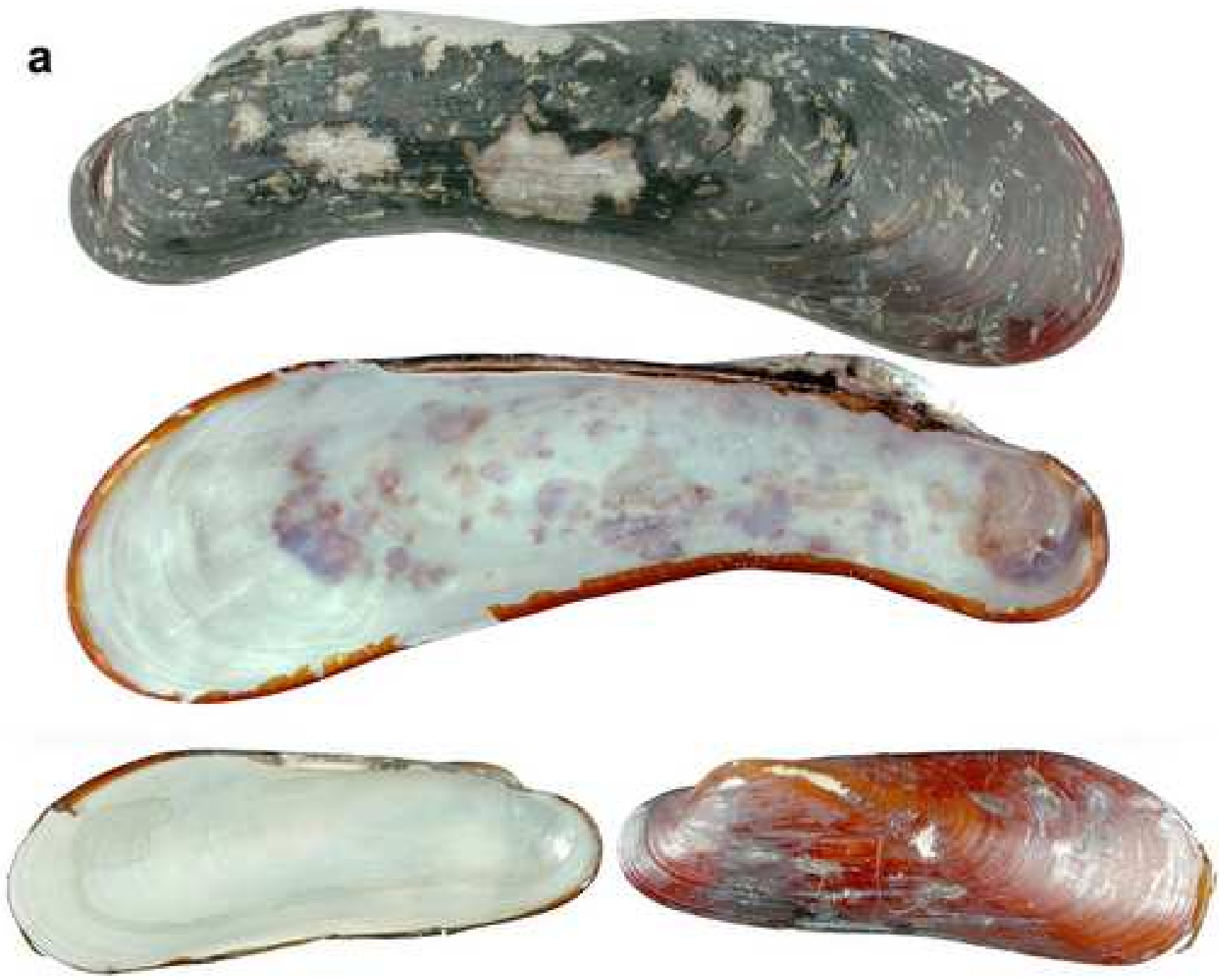
Figure $3 b$

Click here to download high resolution image

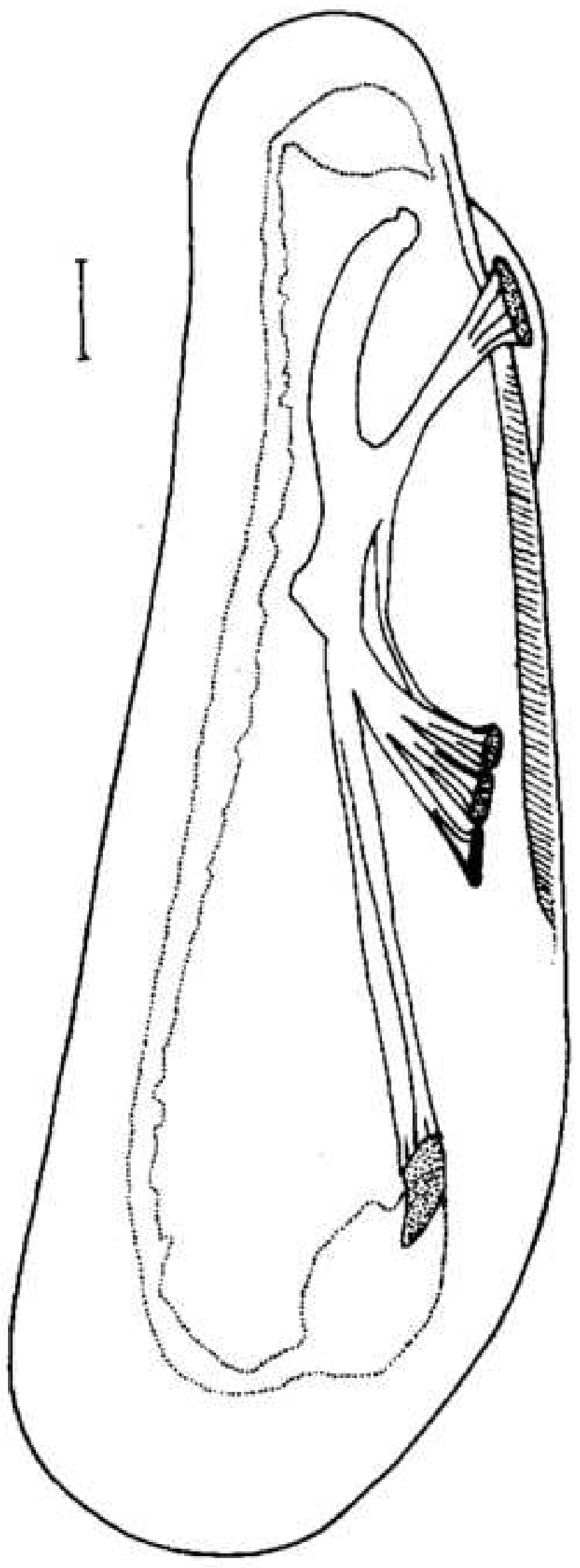


Figure4

Click here to download high resolution image
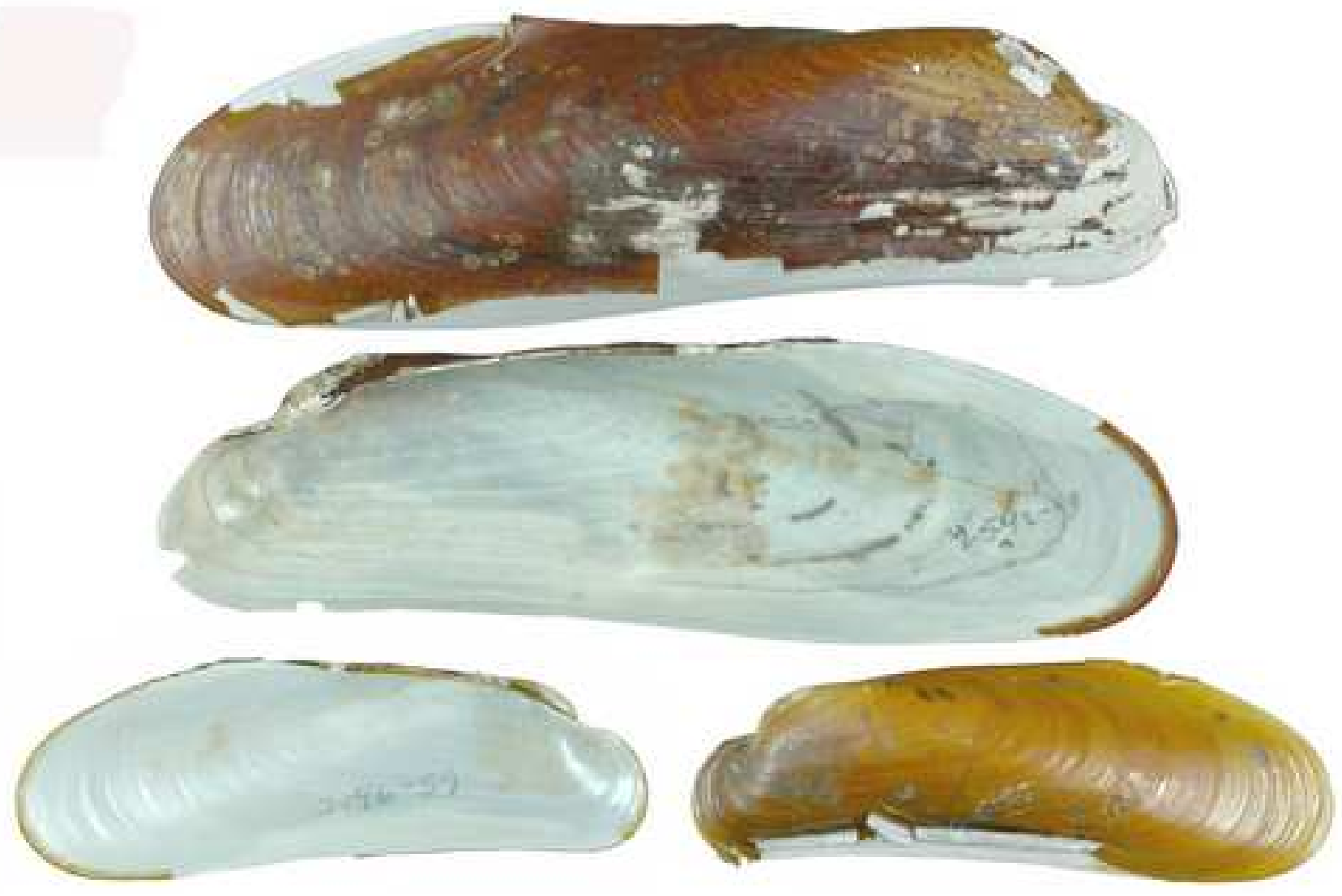
Click here to download high resolution image
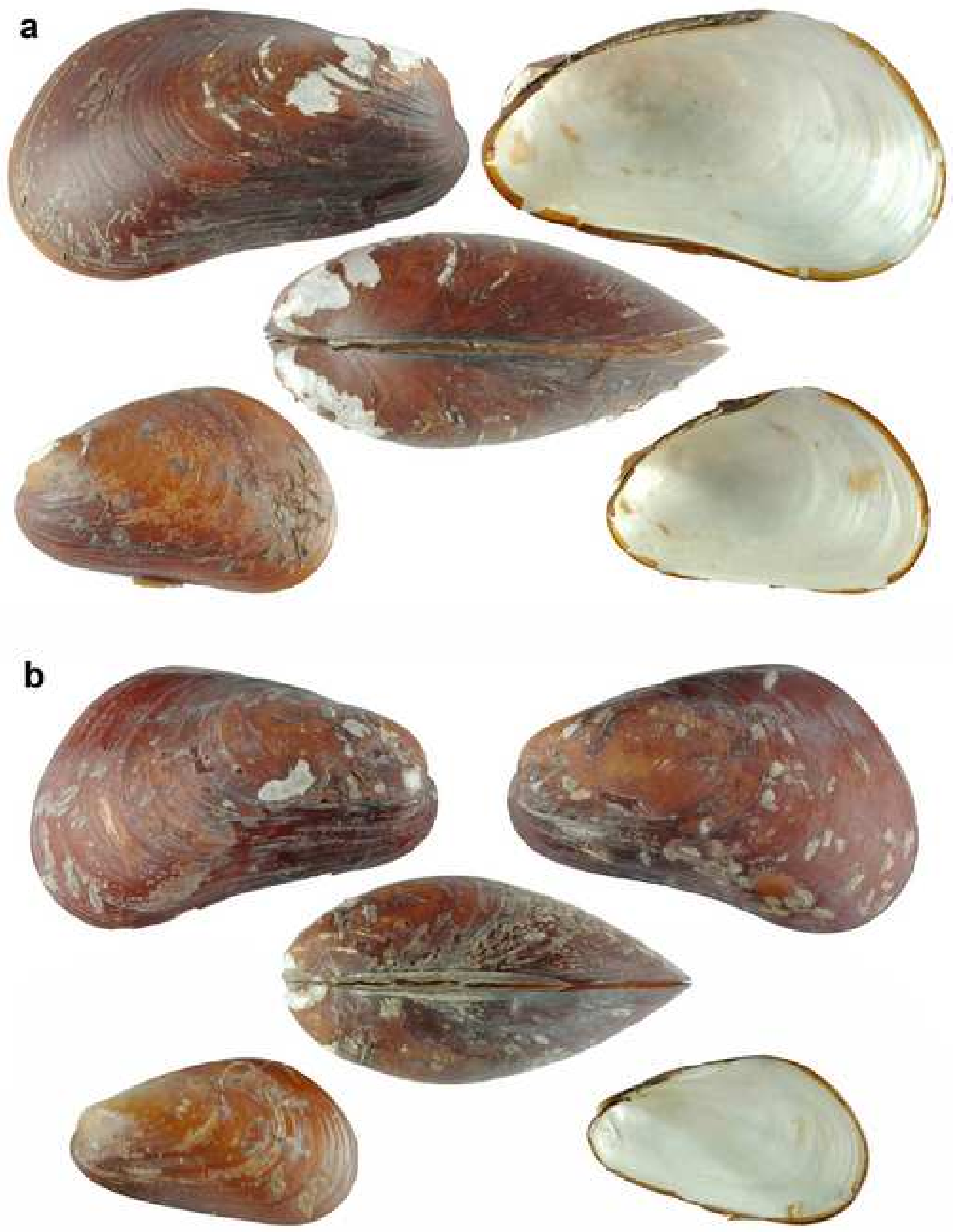
Figure6a
Click here to download high resolution image

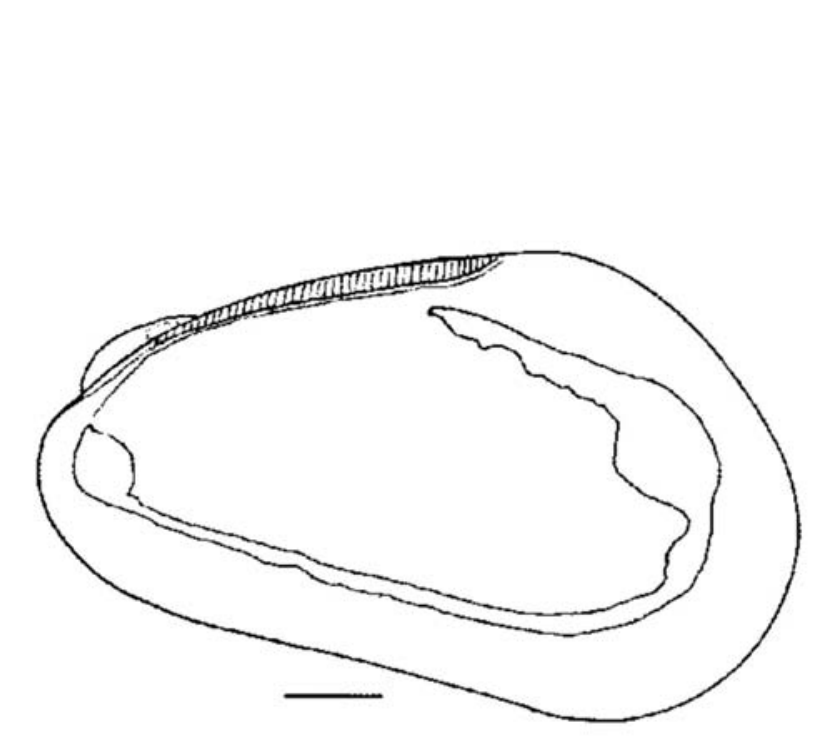


Figurerb
click here to download high resolution image
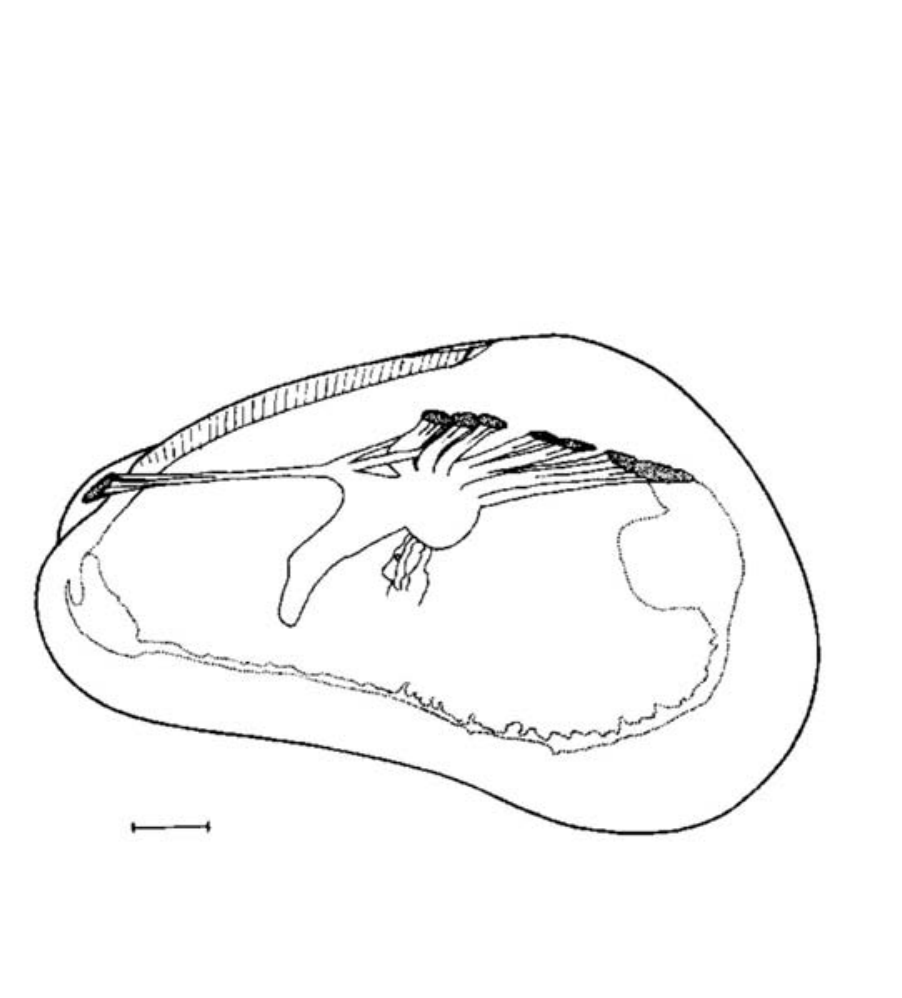

(5)

( (

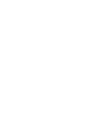

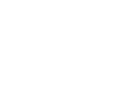

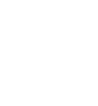

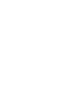

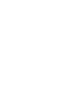

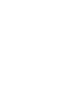
列 . (1) .

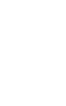
. 
Click here to download Figure: Fig 7.pdf

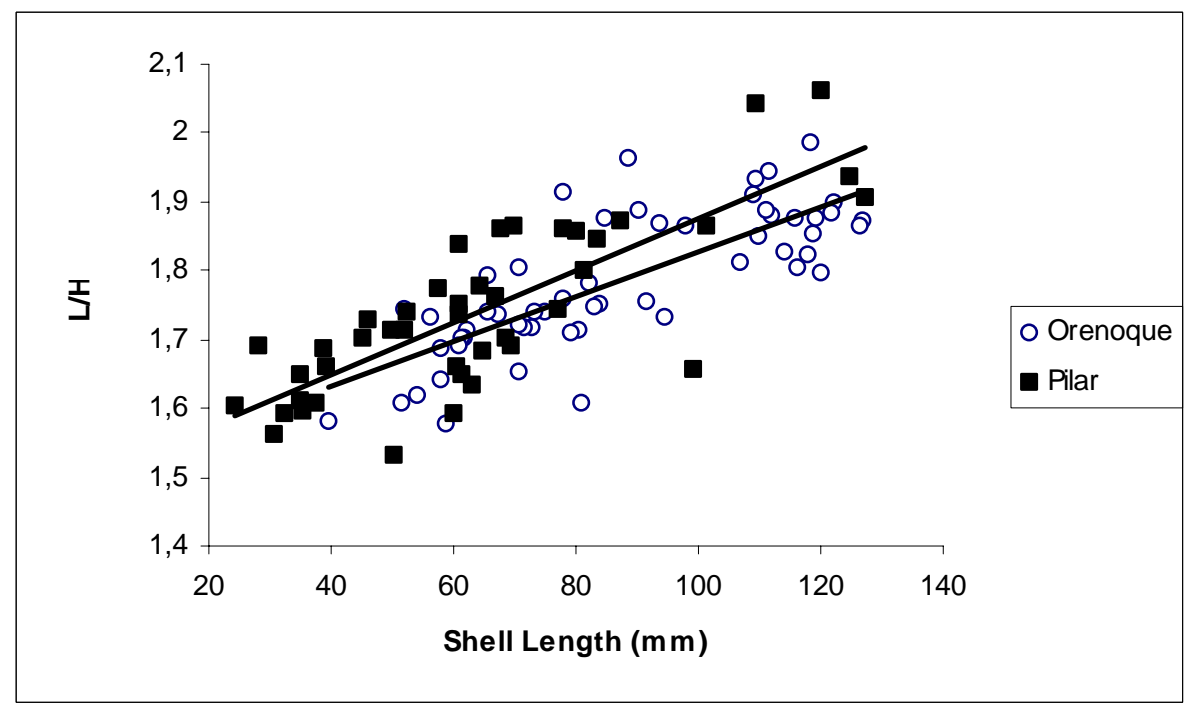


Click here to download high resolution image
Cigure8
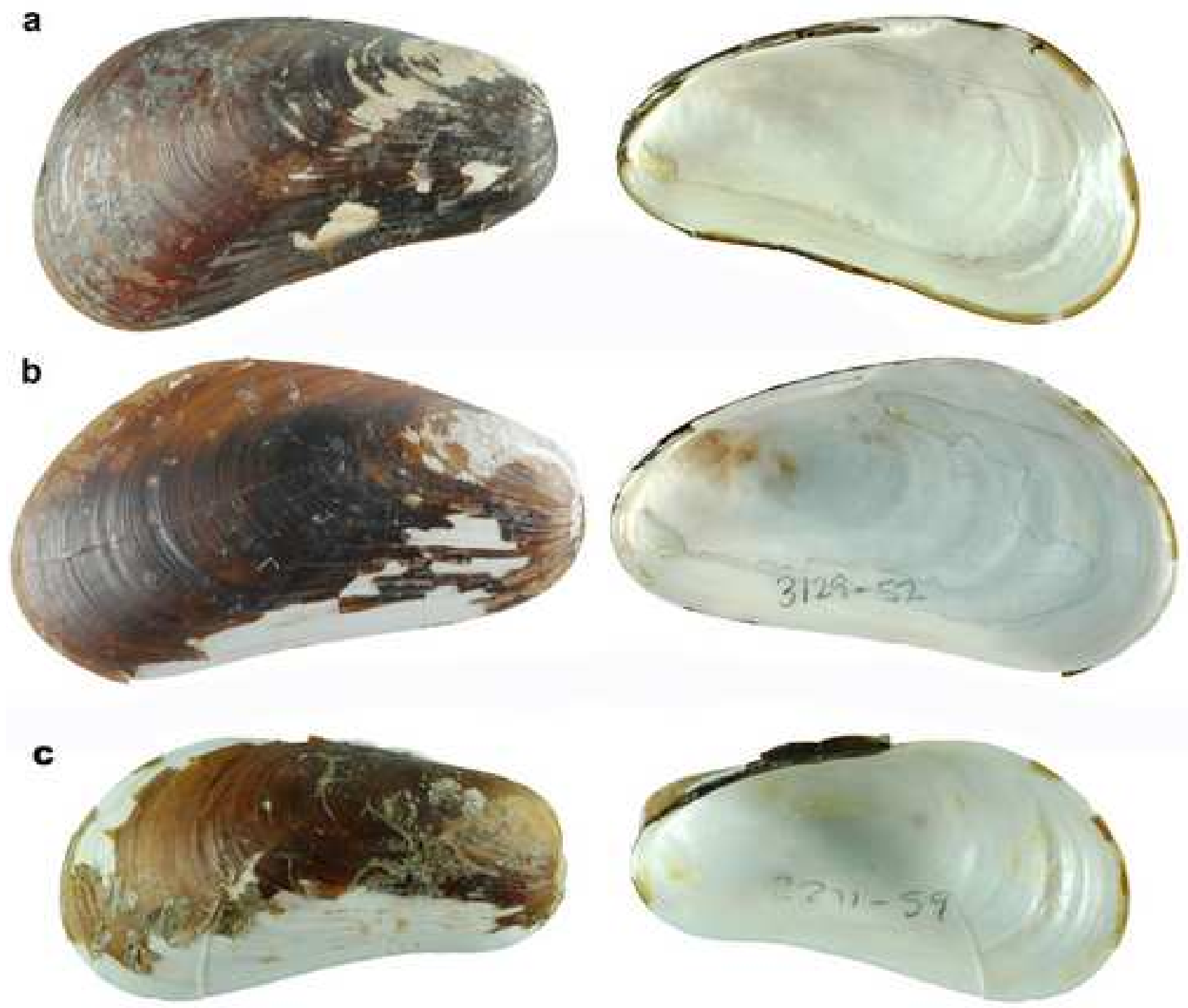
Figure 9

Click here to download high resolution image

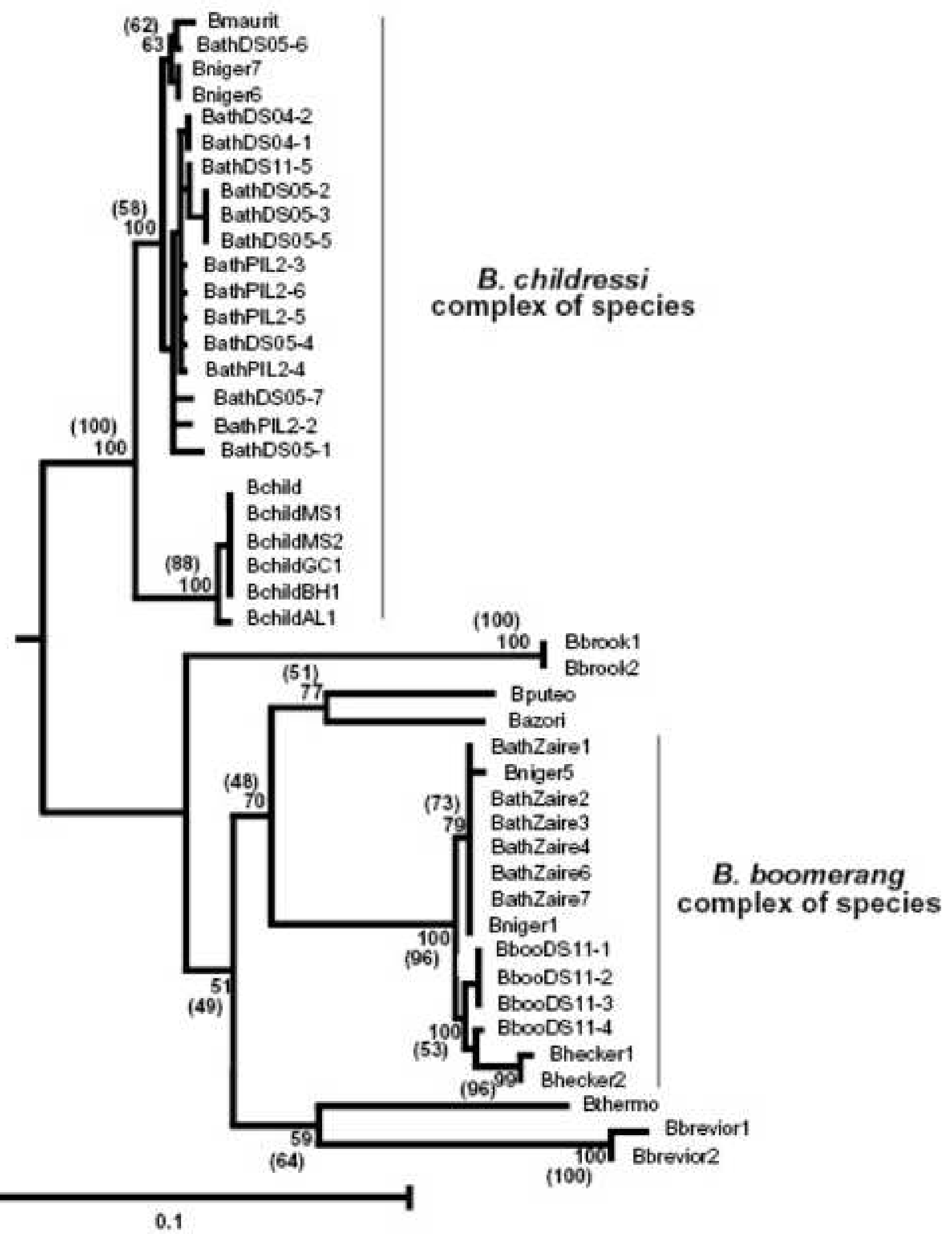

0.1 


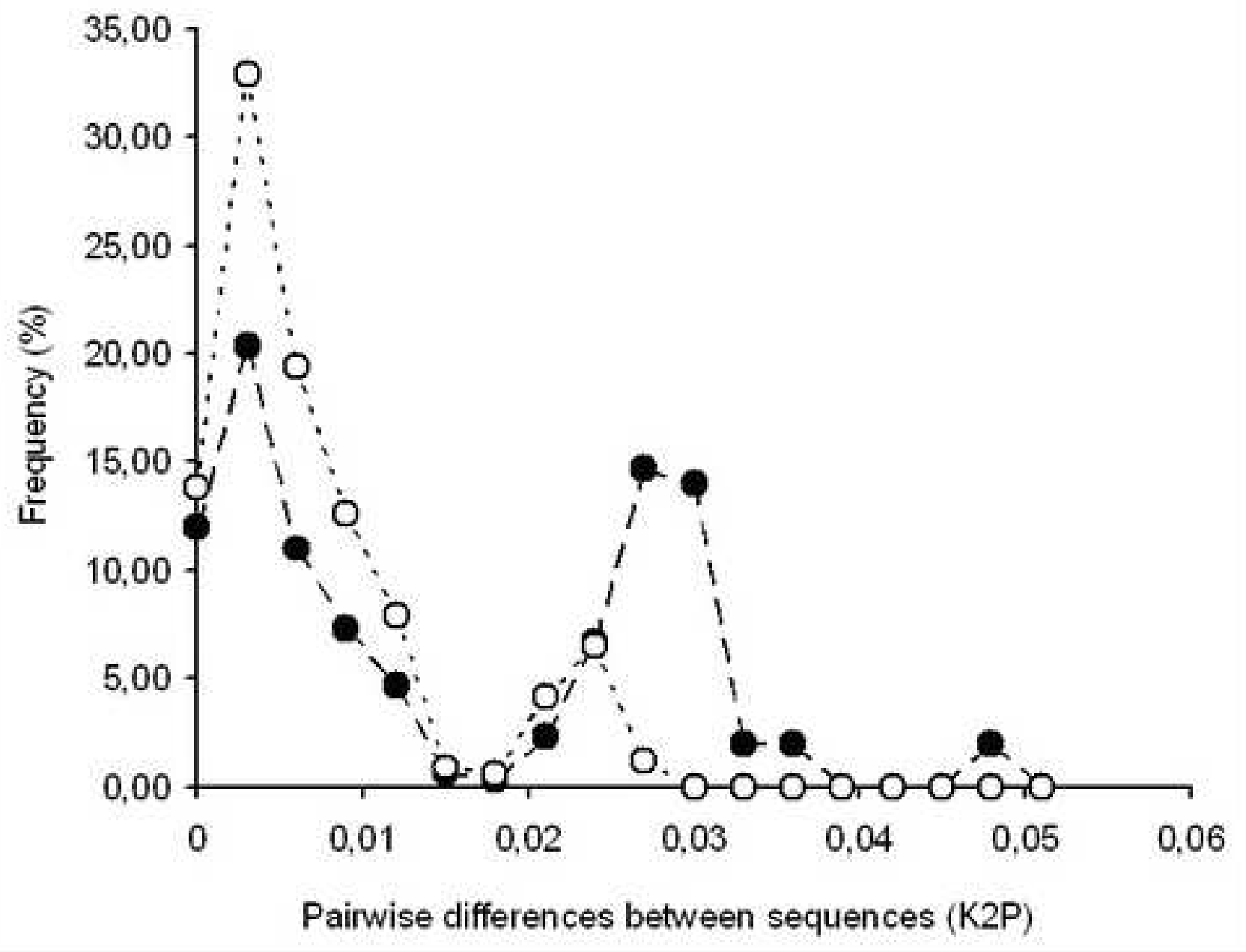


Figure 11
Click here to download high resolution image

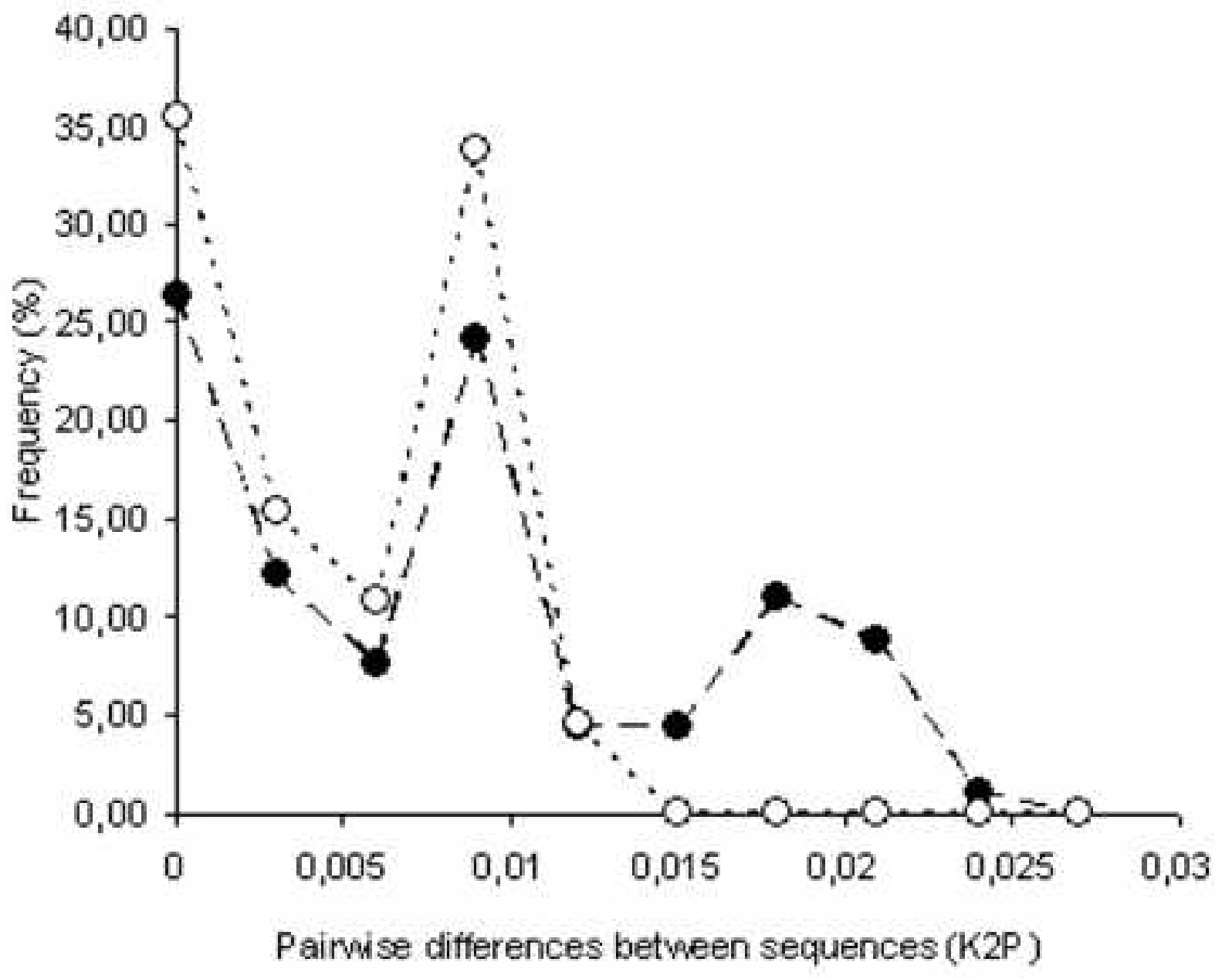


Click here to download Figure: Figure12.pdf

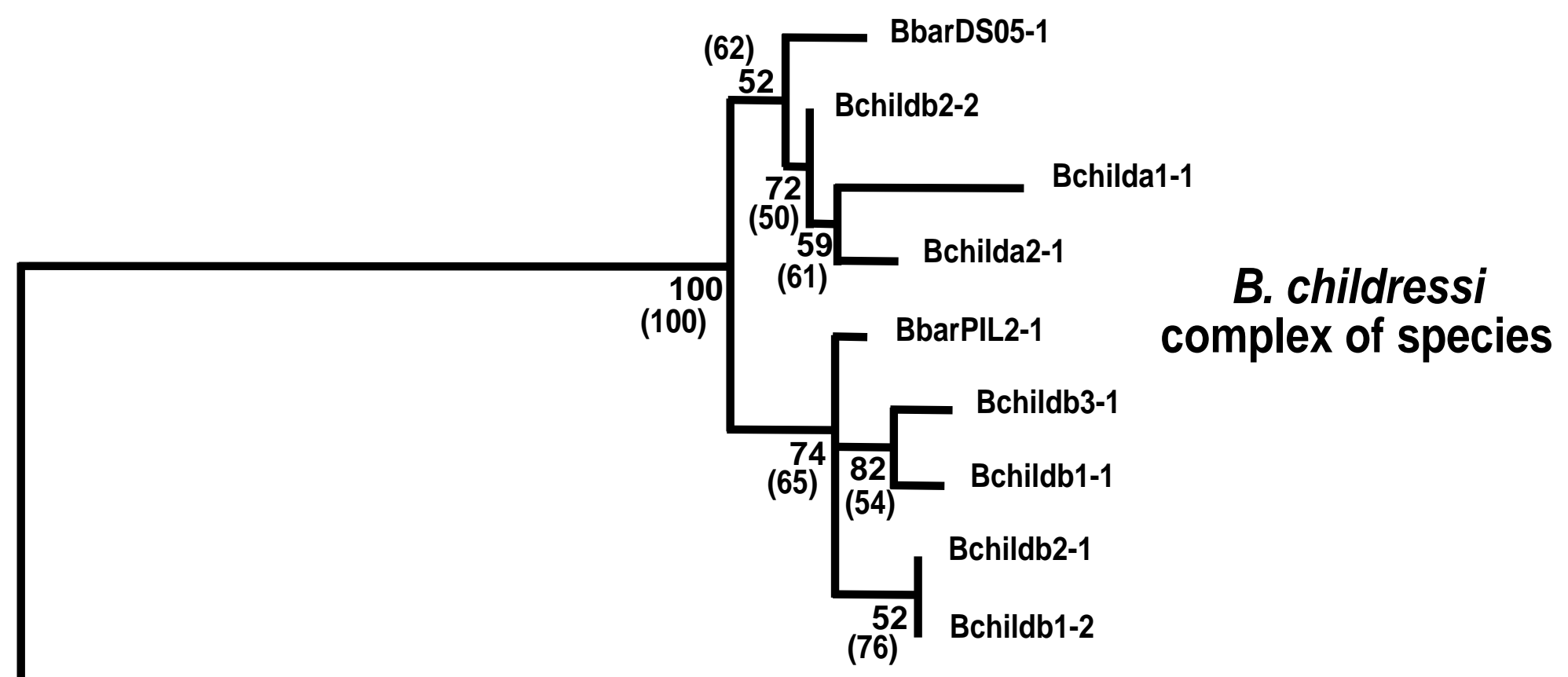

Bthermophilus $\left(13^{\circ} \mathrm{N}\right)$
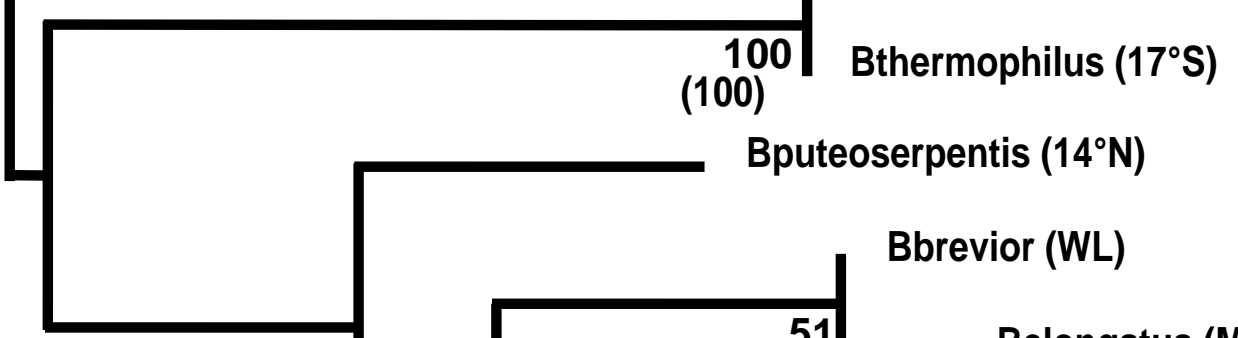

(50)

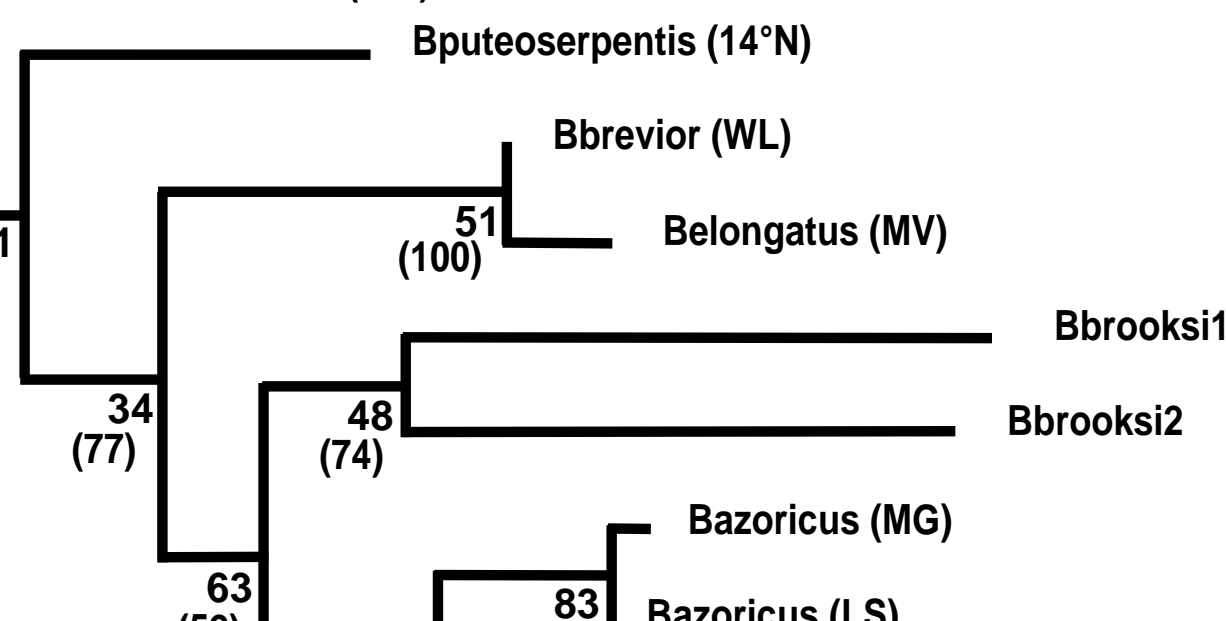

rDNA ITS2 MP Tree

(52)

(97)
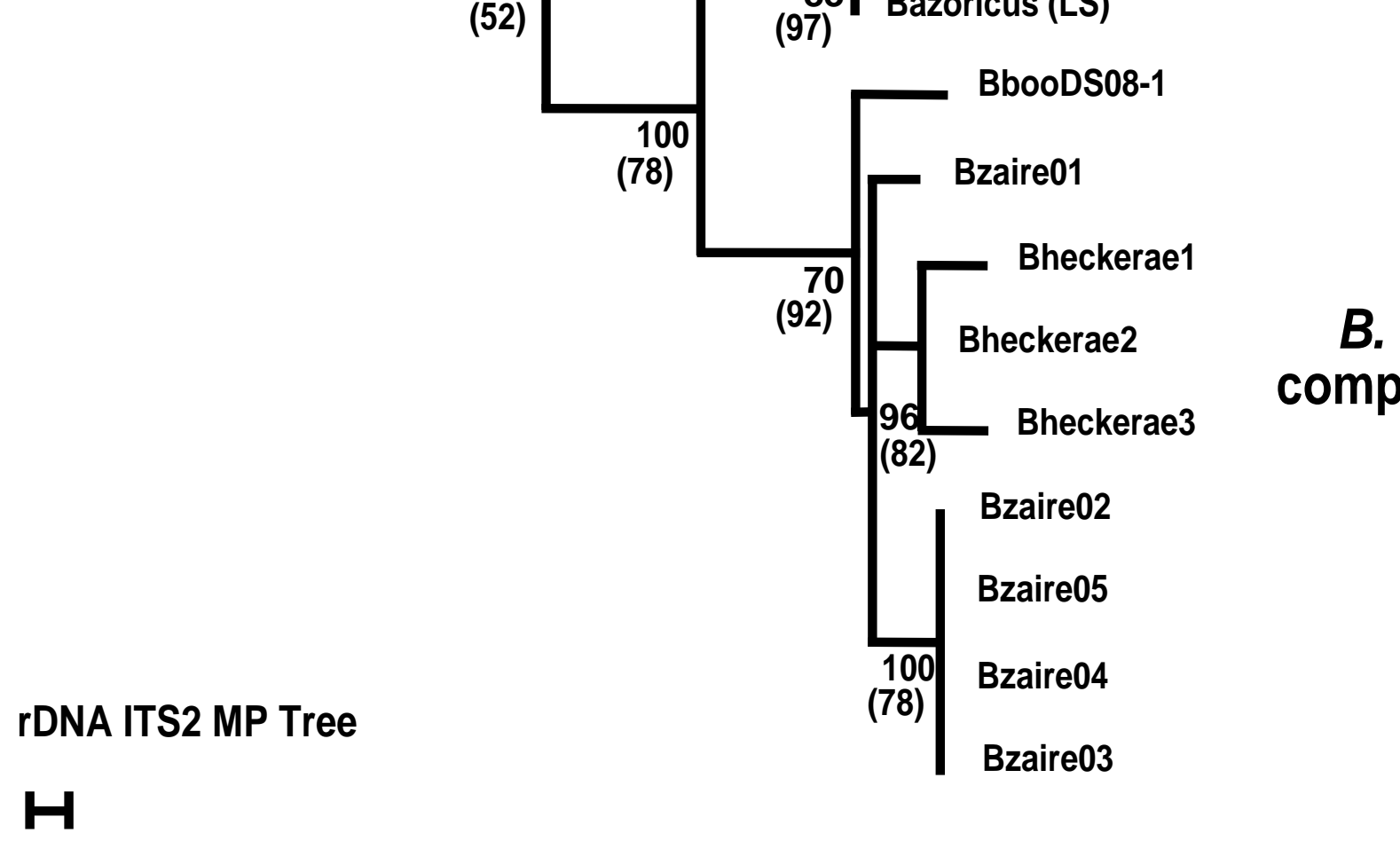

1 state

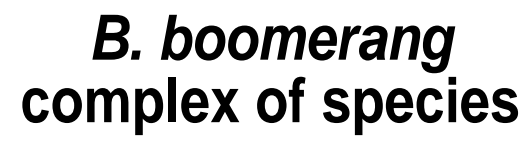
Bheckerae3 (82)

Bheckerae1

(92)

Bheckerae2

Bzaire02

Bzaire05

100 Bzaire04

(78)

Bzaire03 